\title{
Lactational performance and plasma and muscle amino acid concentrations in dairy cows fed diets supplying 2 levels of digestible histidine and metabolizable protein
}

\author{
S. E. Räisänen, ${ }^{1 *}$ C. F. A. Lage,${ }^{1,2} \dagger$ C. Zhou, ${ }^{1,3}$ A. Melgar,,${ }^{1,4}$ T. Silvestre, ${ }^{1}$ D. E. Wasson, ${ }^{1}$ S. F. Cueva, ${ }^{1}$ \\ J. Werner, ${ }^{5}$ T. Takagi, ${ }^{6}$ M. Miura, ${ }^{6}$ and A. N. Hristov ${ }^{1} \ddagger$ \\ ${ }^{1}$ Department of Animal Science, The Pennsylvania State University, University Park 16802 \\ ${ }^{2}$ School of Veterinary Medicine, University of California, Tulare 93274 \\ ${ }^{3}$ University of Chinese Academy of Sciences, Beijing 100049, P. R. China \\ ${ }^{4}$ Agricultural Innovation Institute of Panama (IDIAP), City of Knowledge 07144, Panama \\ ${ }^{5}$ Animal Resource Program, The Pennsylvania State University, University Park 16802 \\ ${ }^{6}$ Ajinomoto Co. Inc., Kawasaki, Japan 210-8681
}

\begin{abstract}
The objective of this experiment was to investigate the effect of dietary levels of digestible histidine (dHis) and $\mathrm{MP}$ on lactational performance and plasma and muscle concentrations of free AA in dairy cows. A randomized block design experiment was conducted with 48 Holstein cows, including 20 primiparous, averaging $( \pm \mathrm{SD})$ $103 \pm 22 \mathrm{~d}$ in milk and $45 \pm 9 \mathrm{~kg} / \mathrm{d}$ milk yield at the beginning of the experiment. A 2-wk covariate period preceded 12 experimental wk, of which 10 wk were for data and sample collection. Experimental treatments were (1) MP-adequate (MPA) diet with $2.1 \%$ dHis of MP (MPA2.1), (2) MPA with 3.0\% dHis (MPA3.0), (3) MP-deficient (MPD) diet with $2.1 \%$ dHis (MPD2.1), and (4) MPD with 3.0\% dHis (MPD3.0). Actual dHis supply was estimated at $64,97,57$, and $88 \mathrm{~g} / \mathrm{d}$, respectively. Diets supplied MP at $110 \%$ (MPA) and 96\% (MPD) of NRC 2001 dairy model requirements calculated based on DMI and production data during the experiment. Dry matter intake and milk yield data were collected daily, milk samples for composition and blood samples for AA analysis were collected every other week, and muscle biopsies at the end of covariate period, and during wk 12 of the experiment. The overall DMI was not affected by dHis or MP level. Milk yield tended to be increased by $3.0 \%$ dHis compared with $2.1 \%$ dHis. Milk true protein concentration and yield were not affected by treatments, whereas milk
\end{abstract}

Received May 28, 2021.

Accepted August 31, 2021.

${ }^{*}$ Current address: Department of Agricultural Sciences, University of Helsinki, PO Box 28, FI-00014 University of Helsinki, Finland.

$\dagger$ Cornell Cooperative Extension, Cornell University, Bath, NY 14810 .

$\ddagger$ Corresponding author: anh13@psu.edu urea nitrogen concentration was lower for MPD versus the MPA diet. Milk fat concentration was lower for MPD versus MPA. There was a MP $\times$ dHis interaction for milk fat yield and energy-corrected milk; milk fat was lower for MPD3.0 versus MPD2.1, but similar for cows fed the MPA diet regardless of dHis level whereas energy-corrected milk was greater for MPA3.0 versus MPA2.1 but tended to be lower for MPD3.0 versus MPD2.1. Plasma His concentration was greater for cows fed dHis3.0, and concentration of sum of essential AA was greater, whereas carnosine, 1-Methyl-His and 3-Methyl-His concentrations were lower for cows fed MPA versus MPD diet. Muscle concentration of His was greater for cows fed dHis3.0 treatment. The apparent efficiency of His utilization was increased at lower MP and His levels. Overall, cows fed a corn silage-based diet supplying MP at $110 \%$ of NRC (2001) requirements tended to have increased ECM yield and similar milk protein yield to cows fed a diet supplying MP at $96 \%$ of requirements. Supplying dHis at $3.0 \%$ of MP (or 86 and $96 \mathrm{~g} / \mathrm{d}$, for MPD3.0 and MPA3.0, respectively) tended to increase milk yield and increased plasma and muscle concentrations of His but had minor or no effects on other production variables in dairy cows.

Key words: histidine, metabolizable protein, milk production

\section{INTRODUCTION}

In dairy farming, excess $\mathrm{N}$, originating from high protein diets, is an environmental burden in terms of $\mathrm{N}$ leakage and ammonia and nitrous oxides emissions, as well as an economic loss for the farmer, as protein is the most expensive major nutrient in dairy rations (Hristov et al., 2011a). One strategy to decrease excess dietary protein without compromising animal performance is to supply adequate amounts of key EAA for maximal 
production while decreasing excess $\mathrm{N}$ excretion (Dijkstra et al., 2013).

In dietary situations where RUP supply is low, as in grass- or corn silage-based diets, microbial protein represents a greater proportion of MP supply. Histidine has been shown to be one of the AA that can become limiting for milk and milk protein synthesis (Vanhatalo et al., 1999; Lee et al., 2012a; Räisänen et al., 2021b). Experiments from our laboratory showed that milk yield (MY) and ECM were increased when rumen-protected His (RPHis) was supplemented on both MPadequate (MPA; according to NRC, 2001; Räisänen et al., 2021a) and MP-deficient (MPD) diets (Räisänen et al., 2021b). However, only when MP supply from the basal diet was deficient did milk protein yield positively respond to RPHis supplementation (Räisänen et al., 2021b). These data further highlighted the fact that His is especially limiting in situations where the cow is more reliant on rumen microbial protein due to its lower His concentration compared with milk protein (Kim et al., 1999). Further, in a 12-wk continuous experiment with MPA basal diet, His became limiting for milk and milk protein production (Giallongo et al., 2017), indicating that a long-term His deficiency can compromise lactational performance even when MP supply is adequate.

Endogenous His from His containing dipeptides mobilized from the muscle, as well as His from blood hemoglobin, has been suggested to partly mask short-term His deficiency (Lapierre et al., 2021). Indeed, muscle His, anserine, and carnosine concentrations have been reported to increase when His has been supplemented on both MPD (Giallongo et al., 2015; Zang et al., 2019) and MPA diets (Giallongo et al., 2017). The mobilization of His from muscle and endogenous sources have made it difficult to determine the extent of His deficiency in lactating dairy cows, to prevent excessive His mobilization and to recommend an optimal dietary supply of dHis.

The objective of this experiment was to investigate the interaction of dietary levels of MP and dHis on lactational performance and plasma and muscle concentrations of AA and dipeptides in a continuous longterm experiment with dairy cows. We hypothesized that long-term His deficiency would compromise lactational performance of the cows, and MP deficiency would amplify the effect of His deficiency.

\section{MATERIALS AND METHODS}

\section{Animals, Housing, and Experimental Design}

All procedures carried out involving animals in this experiment were approved by the Pennsylvania State
University's Institutional Animal Care and Use Committee. A total of 48 lactating Holstein cows, of which 20 primiparous and 28 multiparous averaging $( \pm \mathrm{SD})$ $2.1 \pm 1.3$ in parity, $103 \pm 22 \mathrm{DIM}$, and $45 \pm 9 \mathrm{~kg} / \mathrm{d}$ MY at the beginning of the experiment, were used in a randomized complete block design experiment. A 2-wk covariate period preceded 12 experimental weeks, with $2 \mathrm{wk}$ for diet adaptation and $10 \mathrm{wk}$ of sample and data collection. The cows were blocked in 12 blocks of 4 , based on parity, DIM, and MY at the start of covariate period. Cows were housed in the freestall barn located at the Pennsylvania State University's Dairy Teaching and Research Center. The research pen is equipped with a Calan Broadbent Feeding System (American Calan Inc.) for individual monitoring of DMI, and the cows have free access to drinking water. The cows were fed once daily at around $0800 \mathrm{~h}$ and milked twice daily at around 0630 and $1800 \mathrm{~h}$.

\section{Diets and Treatments}

Four experimental treatments were designed to supply 2 levels of MP and 2 levels of dHis in a factorial design: (1) MPA diet supplying 2.1\% dHis of MP (MPA2.1), (2) MPA supplying 3.0\% dHis of MP (MPA3.0), (3) MPD diet supplying 2.1\% dHis of MP (MPD2.1), and (4) MPD diet supplying 3.0\% dHis of MP (MPD3.0). The experimental diets (Table 1) were originally formulated to be MPA (i.e., meeting or exceeding MP requirements) or 15\% MPD based on NRC (2001) recommendations and the average production data of the experimental cows at the end of covariate period $(26.5$ $\mathrm{kg} / \mathrm{d}$ DMI, $44.4 \mathrm{~kg} / \mathrm{d} \mathrm{MY}$, and $4.03 \%$ milk fat, and $2.94 \%$ milk true protein concentrations). For the $3.0 \%$ dHis treatments (i.e., MPA3.0 and MPD3.0), the basal diets containing $2.1 \%$ dHis (i.e., MPA2.1 and MPD2.1) were supplemented with RPHis (an experimental, fat-coated product, by Ajinomoto Inc., containing $88 \%$ L-His of $\mathrm{CP}$, rumen escape of $52 \%$, and intestinal digestibility of $98 \%$, based on manufacturer's specifications). The MPA2.1 and MPD2.1 diets were supplemented with stearic acid (80\% purity, Cargill Animal Nutrition) to compensate for the fat from coating of RPHis (Table 1). The MPD diet was supplemented with urea ( $46 \% \mathrm{~N}$ of DM; Kirby Agri) to compensate for the lower RDP concentration of this diet. All diets were supplemented with RPMet (Mepron, Evonik Operations GmbH) and RPLys (AjiPro-L, Ajinomoto Inc.) to meet or exceed the dMet and dLys recommendations (NRC, 2001; Schwab et al., 2005). The daily doses of RPHis, RPMet, RPLys, urea, and stearic acid were weighed as a premix and mixed in the TMR as it was prepared daily in a mobile TMR mixer (Rissler Mobile TMR mixer Model 1050; I. H. Risller) at the time of feeding. Intake 
Table 1. Ingredient and chemical composition of the diets used in the experiment

\begin{tabular}{|c|c|c|c|c|}
\hline \multirow[b]{2}{*}{ Item } & \multicolumn{4}{|c|}{$\operatorname{Diet}^{1}$} \\
\hline & MPA2.1 & MPA3.0 & MPD2.1 & MPD3.0 \\
\hline \multicolumn{5}{|l|}{ Feed ingredient, ${ }^{2} \%$ of DM } \\
\hline Corn silage & 45.1 & 45.0 & 45.2 & 45.1 \\
\hline Alfalfa haylage & 10.8 & 10.7 & 10.8 & 10.8 \\
\hline Hay and wheat straw mix & 3.43 & 3.43 & 3.38 & 3.36 \\
\hline Canola meal & 12.4 & 12.4 & 12.5 & 12.5 \\
\hline Ground corn & 7.84 & 7.80 & 12.8 & 12.8 \\
\hline SoyPLUS & 6.90 & 6.88 & 2.03 & 2.03 \\
\hline GreenFeed bait feed $^{3}$ & 4.79 & 5.27 & 5.05 & 6.64 \\
\hline Molasses & 4.93 & 4.92 & 5.06 & 5.05 \\
\hline Whole cottonseed & 4.85 & 4.85 & 4.73 & 4.71 \\
\hline Whole roasted soybeans & 1.98 & 1.97 & 1.69 & 1.68 \\
\hline Mineral $\operatorname{mix}^{4}$ & 1.05 & 1.04 & 1.01 & 1.01 \\
\hline RPHis & - & 0.59 & - & 0.56 \\
\hline AjiPro-L & 0.33 & 0.33 & 0.24 & 0.24 \\
\hline Urea & - & - & 0.22 & 0.22 \\
\hline Stearic acid & 0.24 & - & 0.23 & - \\
\hline Mepron & 0.14 & 0.14 & 0.11 & 0.11 \\
\hline \multicolumn{5}{|c|}{ Nutrient composition, ${ }^{5} \%$ of DM } \\
\hline $\mathrm{CP}$ & 16.6 & 16.9 & 15.3 & 15.5 \\
\hline NDF & 32.9 & 32.8 & 32.6 & 32.4 \\
\hline $\mathrm{ADF}$ & 21.3 & 21.3 & 21.1 & 21.0 \\
\hline $\mathrm{NFC}$ & 43.4 & 43.3 & 45.2 & 45.1 \\
\hline Starch & 23.3 & 23.0 & 24.6 & 25.3 \\
\hline Ether extract & 4.97 & 4.98 & 4.75 & 4.74 \\
\hline $\mathrm{NE}_{\mathrm{L}},{ }^{6} \mathrm{Mcal} / \mathrm{kg}$ & 1.59 & 1.59 & 1.58 & 1.58 \\
\hline Ash & 4.26 & 4.28 & 4.01 & 4.03 \\
\hline $\mathrm{Ca}$ & 0.70 & 0.60 & 0.60 & 0.60 \\
\hline $\mathrm{P}$ & 0.50 & 0.50 & 0.50 & 0.50 \\
\hline
\end{tabular}

${ }^{1}$ MPA2.1 and MPA3.0 were formulated to supply adequate MP according to NRC (2001) and 2.1 and $3.0 \%$ digestible His of MP, respectively. MPD2.1 and MPD3.0 were formulated to be around $80 \%$ deficient in MP and to supply 2.1 and $3.0 \%$ of MP, respectively.

${ }^{2}$ Corn silage was $40.5 \% \mathrm{DM}$ and contained (DM basis) $6.9 \% \mathrm{CP}$ and $39.6 \% \mathrm{NDF}$; alfalfa haylage was $46.5 \% \mathrm{DM}$ and contained (DM basis) $18.2 \% \mathrm{CP}$ and $39.1 \% \mathrm{NDF}$; hay and wheat straw mix was $89.6 \% \mathrm{DM}$ and contained (DM basis) $8.0 \% \mathrm{CP}$ and 71.2\% NDF; SoyPLUS: Landus Cooperative; GreenFeed: C-Lock Inc.; molasses: Westway Feed Products; AjiPro-L: Ajinomoto Co. Inc.; Mepron: Evonik Operations GmbH; rumen-protected His (RPHis): experimental, fat-coated product by Ajinomoto Co Inc.

${ }^{3}$ Stocker Grower 14; Purina Animal Nutrition LLC. See Material and Methods section for details.

${ }^{4}$ Mineral and vitamin premix (Cargill Animal Nutrition, Cargill Inc.) contained (\%, as-is basis) limestone, 36.75; dry corn distillers grains with solubles, 29.00; NaCl, 24.85; MgO (54\% Mg), 4.15; Bio-Phos (Rootwise Soil Dynamics), 2.45; zinc sulfate, 0.96; mineral oil, 0.5; vitamin E, 0.37; manganese sulfate, 0.37; copper sulfate, 0.26; ferrous sulfate, 0.16; selenium, 0.13; vitamin A, 0.03; vitamin $\mathrm{D}_{3}, 0.013$; calcium iodate, 0.008 ; cobalt carbonate, 0.005 .

${ }^{5}$ Unless indicated otherwise, values were calculated using the chemical analysis (Cumberland Valley Analytical Services Inc., Waynesboro, PA) of individual feed ingredients and their inclusion rates in the diet.

${ }^{6}$ Values estimated based on NRC (2001).

of TMR was recorded daily and feeding rate adjusted to yield refusals equal to 5 to $10 \%$ of the feed consumed in the previous day.

\section{Sample Collection and Measurements}

Feed and TMR Sampling. Forage, TMR and refusal samples were collected twice weekly and concentrate feeds once a week and stored at $-20^{\circ} \mathrm{C}$. All feed samples were dried in a forced-air oven at $55^{\circ} \mathrm{C}$ for $72 \mathrm{~h}$ and ground in a Wiley mill (Thomas Scientific) through a 1-mm sieve. Four composited forage samples (1 for every 3 experimental wk) and one composited sample of each concentrate feed were submitted to Cumberland Valley Analytical Services (Waynesboro, PA) for wet chemistry analysis for CP (method 990.03; AOAC International, 2000), amylase-treated NDF (Van Soest et al., 1991), ether extract (method 2003.05; AOAC International, 2006), ADF (method 973.18; AOAC International, 2000), ash (method 942.05; AOAC International, 2000), minerals (method 985.01; AOAC International, 2000), and estimated NFC (NRC, 2001). Further, composited forage and concentrate samples were analyzed for AA at the University of Missouri- 
Columbia's Agricultural Experiment Station Chemical Laboratories, (Columbia, MO) following the procedures of Deyl et al. (1986) and Fekkes (1996). Nutrient composition of the 4 diets were calculated from analyzed values of individual feed ingredients and intake of the GreenFeed bait feed (see below; nutrient composition based on manufacturer's specifications), and their inclusion rate in the TMR (Table 1 ).

Milk Sampling. Milk samples for composition analysis were collected on the last week of the covariate period and every other week during the experimental period from 2 consecutive p.m. and a.m. milkings (i.e., a total of 4 milk samples/wk). Samples were collected into 20-mL tubes, preserved with 2-bromo-2-nitropropane-1,3-diol and analyzed for milk fat, true protein, MUN, and lactose concentrations by Dairy One laboratory (Itacha, NY) using infrared spectroscopy and Milkoscan models 6000, FT+, or 7 and Fossomatic models 5000 of FC (Foss Electric A/S). Milk yield and BW of the cows were recorded at each milking.

Fecal and Urine Sampling. Four fecal and urine samples each were collected from each experimental cow over $2 \mathrm{~d}$ on wk 11, at 1100 and $1930 \mathrm{~h}$ on d 1 and at 0730 and $1500 \mathrm{~h}$ on d 2. Approximately $500 \mathrm{~g}$ of fecal sample was collected by rectal stimulation and immediately dried at $55^{\circ} \mathrm{C}$ to constant weight. The dried samples were ground using a Wiley mill through a 1-mm sieve and composited by cow. Composited fecal samples were then analyzed for total N using a Costech ECS 4010 elemental analyzer (Costech Analytical Technologies Inc.), indigestible NDF (iNDF), ADF, and NDF with Ankom 200 fiber analyzer (Ankom technology Corp.) and starch (Hall, 2009) to determine total-tract N, $\mathrm{NDF}, \mathrm{ADF}$, and starch digestibility. Indigestible NDF was used as a total-tract digestibility marker (Schneider and Flatt, 1975). Composited fecal samples and TMR samples collected on wk 11 were dried at $55^{\circ} \mathrm{C}$, ground through a 1-mm screen and incubated for $12 \mathrm{~d}$ in the rumen of a lactating rumen-cannulated cow for analysis of iNDF (Huhtanen et al., 1994; Lee et al., 2012a).

Urine samples were collected at the same time points as for the fecal samples by stimulation of the vulva and filtered through 2 layers of cheesecloth. Aliquots of 10 $\mathrm{mL}$ of urine samples were acidified with $0.6 \mathrm{~mL}$ of $2 M$ sulfuric acid and diluted 1:10 with $90 \mathrm{~mL}$ of distilled water, and stored at $-20^{\circ} \mathrm{C}$ until analysis. Samples were composited by cow and analyzed for allantoin (Chen et al., 1992), uric acid (Stanbio Uric Acid Kit 1045; Stanbio Laboratory Inc.), urea N (Stanbio Urea Nitrogen Kit 580; Stanbio Laboratory Inc.) and creatinine (Stanbio Creatinine Kit 420; Stanbio Laboratory Inc.). Aliquots of the urine composite samples were freezedried and analyzed for total N using Costech ECS 4010 elemental analyzer. Urinary creatinine concentration was used to estimate daily urine output, assuming a creatinine excretion rate of $29 \mathrm{mg} / \mathrm{kg}$ of BW (based on unpublished total urine collection data by Hristov et al., 2011b). Daily excretions of total N, urea N, and purine derivates (PD; allantoin and uric acid) were calculated based on the estimated daily urine output.

Blood Sampling. Blood samples were collected from the tail vein or artery of the cows on wk 2 of covariate period and during each experimental wk (wk 3-12) at $1100 \mathrm{~h}$ (i.e., $3 \mathrm{~h}$ after feeding) into Vacutainer tubes containing EDTA (Becton, Dickinson and Co.) and analyzed for hemoglobin concentration on the day of sampling. Additional blood samples were collected during wk 2 of covariate period and every 2 wk during the experimental period, 4 times in 2 consecutive days, at 1100 and $1600 \mathrm{~h}$ on $\mathrm{d} 1$ and at 1400 and $2000 \mathrm{~h}$ on d 2. Blood was collected into Vacutainer tubes containing EDTA and plasma was separated by centrifuging at $1,500 \times g$ and $4^{\circ} \mathrm{C}$ for 15 min. Plasma samples were composited as follows: 1 sample per cow for the covariate period, a second sample per cow for wk 3 of the experimental period, a third sample for wk 4 , and a fourth composite sample per cow for wk $6,8,10$, and 12. Composited plasma samples were analyzed for AA concentration by Ajinomoto Inc. using a High-Speed AA analyzer L-8900 (Hitachi High-Technologies Co.).

Muscle Biopsies. Muscle biopsies from the longissimus dorsi were obtained from all cows on wk 2 of the covariate period and on wk 12 of the experimental period. During the procedure, cows were immobilized in a cattle chute. The surgical area, between the 12th and 13 th transverse processes, was shaved and disinfected by alternating scrubs of $7.5 \%$ povidone iodine and $99 \%$ isopropyl alcohol. A 1-cm incision was performed under local anesthesia ( $8 \mathrm{~mL}$ of $2 \%$ lidocaine- $\mathrm{HCl}$ ) to expose the muscle with a sterile scalpel blade. An 8-mm sterile biopsy punch (Miltex Inc.) was used to remove around $1 \mathrm{~g}$ of muscle tissue, and the incision was closed with a simple interrupted absorbable suture. The sample was immediately weighed and placed in liquid $\mathrm{N}_{2}$, and later stored at $-80^{\circ} \mathrm{C}$. The tissue samples were homogenized with a Polytron homogenizer (Polytron PT 10-35; Kinematica $\mathrm{GmbH}$ ) in ice-cold buffer containing $20 \mathrm{mM}$ HEPES (SAFC), 2 EGTA m $M$ (Sigma Aldrich), $50 \mathrm{~m} M$ $\mathrm{NaF}, 100 \mathrm{~m} M \mathrm{KCl}$ (Fisher Scientific), $0.2 \mathrm{~m} M$ EDTA (Dot Scientific, Inc.), $50 \mathrm{~m} M \beta$-glycerophosphate (EMD Millipore), $1 \mathrm{~m} M$ DTT (Roche Diagnostic, GmbH), 1 $\mathrm{m} M$ benzamidine (EMD Millipore), $0.5 \mathrm{~m} M$ sodium vanadate (Pfaltz \& Bauer) $0.1 \mathrm{~m} M$ PMFS (Dot Scientific, Inc.) and centrifuged at $10,000 \times g$ at $4^{\circ} \mathrm{C}$ for 10 min (Lang et al., 2003). The supernatant was collected and analyzed for AA at the University of Missouri- 
Columbia's Agricultural Experiment Station Chemical Laboratories (Columbia, MO) following the procedures of Deyl et al. (1986) and Fekkes (1996).

Enteric Gas Emissions. For enteric gas emissions measurements, the cows had access to 2 GreenFeed units (C-Lock Inc.), which dispensed a pelletized bait feed (Stocker Grower 14, Purina Animal Nutrition LLC). The weight of the dispensed pellets was recorded at each individual visit. Each cow was allowed a maximum of 6 visits in $24 \mathrm{~h}$, with a 4 -h interval between visits, and no more than 12 feed drops of approximately $35 \mathrm{~g}$ each per visit. The total number of visits during the experiment was 16,610 , averaging at $4 \pm 2$ visits/ cow per day. At the end of the experiment, daily intake of pellets was added in the daily DMI for each cow, and an averaged pellet intake for each treatment was used to calculate the inclusion rates in the reconstituted diets at the end of the experiment (Table 1). Cows were adapted to using the GreenFeed units before the start of the covariate period and were identified with a unique radio-frequency identification ear tag. They visited the units voluntarily and enteric gas emissions were measured at each visit. GreenFeed units were calibrated following the manufacturer's recommendations (http://greenfeed.c-lockinc.com). Biweekly average of DMI and MY, and ECM yield were used to estimate biweekly averages of $\mathrm{CH}_{4}$ yield (i.e., $\mathrm{g} / \mathrm{kg}$ ) and intensity (i.e., g/kg MY or ECM).

Calculated Histidine Pools and Efficiency of Utilization. Apparent dHis recovery was calculated based on an estimated dHis intake (NRC, 2001), and measured blood and milk protein concentrations as detailed in Räisänen et al. (2021a,b). In short, the amount of His in blood His pool included His in blood hemoglobin, plasma free His, as well as His in plasma 1-methyl-His (1-MH), 3-methyl-His (3-MH), and carnosine. The amount of His in these metabolites was based on the proportion of His molecular weight in the molecular weight of the metabolite in question. The amount of His in plasma and blood pools were calculated based on an assumed blood volume of $6.7 \%$ of BW, and plasma volume of $68 \%$ of blood volume (Reynolds, 1953). Histidine concentration in milk CP was assumed to be $2.7 \%$ based on an averaged value from Lee et al. (2015). Apparent recovery of dHis in milk His pool was calculated as milk His $(\mathrm{g} / \mathrm{d}) \div$ dHis intake $(\mathrm{g} / \mathrm{d}) \times 100$. Apparent recovery of dHis in blood was calculated as total His in blood $(\mathrm{g}) \div \mathrm{dHis}$ intake $(\mathrm{g} / \mathrm{d}) \times 100$, where total His in blood was the sum of plasma His (g), His in 1-MH and His in hemoglobin. Apparent recovery of dHis in blood and milk His pools was calculated as [Total blood His $(\mathrm{g})+$ milk His $(\mathrm{g} / \mathrm{d})] \div$ dHis intake $(\mathrm{g} / \mathrm{d})$ $\times$ 100. Apparent efficiency of His utilization $\left(\right.$ Eff $\left._{\mathrm{His}}\right)$ was calculated as described in Lapierre et al. (2021):
$\mathrm{Eff}_{\mathrm{His}}=$ sum of His in true exported proteins $(\mathrm{g}) \div$ [digestible His flow $(\mathrm{g})$ - endogenous urinary loss of His (g)]. Where the sum of His in true exported proteins includes milk true protein yield, and estimated scurf and metabolic fecal protein were calculated as detailed in Lapierre et al. (2021).

\section{Statistical Analysis}

All data were analyzed using the MIXED procedure of SAS (version 9.4, SAS institute Inc.). Data were tested for normality using the UNIVARIATE procedure of SAS and processed for outliers based on the absolute studentized residue value $>3$ (using PROC REG of SAS). Dry matter intake, MY, BW, feed efficiency, and hemoglobin data were averaged weekly, and milk composition, ECM, ECM feed efficiency, $\mathrm{NE}_{\mathrm{L}}$, and the enteric gas emission data were averaged biweekly. The statistical model included week as the repeated term for weekly data and time for the biweekly data, and MP and His level as fixed effects. The best covariance structure for repeated measures was chosen based on the lowest Akaike information criterion, and were AR(1) for DMI, feed efficiency, BW, blood hemoglobin, milk fat and protein concentration, MUN, and milk true protein yield, $\mathrm{CO}_{2}$ and some plasma $\mathrm{AA} ; \mathrm{ARH}(1)$ for MY, ECM, ECM feed efficiency, NEL, milk fat and lactose yields, other gas emissions data, methane yield and intensity, as well as some plasma AA; and $\mathrm{CSH}$ for milk lactose concentration and some plasma AA. Interaction of MP level $\times$ week, His level $\times$ week, as well as MP level $\times$ His level were included in the model where significant, and nonsignificant interactions are not reported. Block and block $\times$ MP level $\times$ His level were considered random effects. Digestibility, N excretion, His pool, and muscle AA concentration data were analyzed with the same model without the repeated term and interactions. The means separation was done using the PDIFF procedure of SAS and all data are presented as covariate-adjusted LSM of MPA versus MPD, and dHis2.1 versus dHis3.0. Statistical differences were considered significant at $P \leq 0.05$, and a trend at $0.05<P \leq 0.10$.

\section{RESULTS}

The 2 basal diets (MPA and MPD) differed most notably in the amount of ground corn and SoyPLUS but had similar nutrient composition except for CP (Table 1). All treatments provided adequate $\mathrm{NE}_{\mathrm{L}}$ (Table 2), whereas MPA2.1 and MPA3.0 supplied 110 and 109\%, and MPD2.1 and MPD3.0 supplied 97 and 96\% of MP requirements according to NRC (2001), respectively. 
Table 2. Dietary net energy of lactation, protein fractions, and AA supply and balance ${ }^{1}$ in mid-lactation dairy cows fed an MP-adequate (MPA) or MP-deficient (MPD) diet with 2 levels of digestible (d)His

\begin{tabular}{|c|c|c|c|c|}
\hline \multirow[b]{2}{*}{ Item } & \multicolumn{4}{|c|}{ Diet $^{2}$} \\
\hline & MPA2.1 & MPA3.0 & MPD2.1 & MPD3.0 \\
\hline \multicolumn{5}{|l|}{$\mathrm{NE}_{\mathrm{L}}, \mathrm{Mcal} / \mathrm{d}$} \\
\hline Requirement & 39.3 & 41.6 & 38.9 & 38.5 \\
\hline Supply & 42.8 & 44.1 & 41.8 & 41.7 \\
\hline Balance & 3.5 & 2.5 & 2.9 & 3.2 \\
\hline \multicolumn{5}{|l|}{ Protein fractions, $\mathrm{g} / \mathrm{d}$} \\
\hline \multicolumn{5}{|l|}{ MP } \\
\hline Requirement & 2,818 & 2,985 & 2,809 & 2,880 \\
\hline Supply & 3,105 & 3,265 & 2,726 & 2,759 \\
\hline Balance & 287 & 280 & -89 & -121 \\
\hline Supply $\div$ requirement & 1.10 & 1.09 & 0.97 & 0.96 \\
\hline \multicolumn{5}{|l|}{ RDP and RUP } \\
\hline RDP supply & 2,618 & 2,773 & 2,600 & 2,614 \\
\hline RDP balance & -71 & -59 & -52 & -30 \\
\hline RUP supply & 1917 & 2048 & 1,624 & 1,552 \\
\hline RUP balance & 354 & 347 & -106 & -155 \\
\hline \multicolumn{5}{|l|}{ AA balance, $\mathrm{g} / \mathrm{d}$} \\
\hline $\begin{array}{l}\text { dHis } \\
\text { Intended supply }{ }^{3}\end{array}$ & 56 & 90 & 56 & 86 \\
\hline Dietary supply & 64 & 97 & 57 & $\begin{array}{l}00 \\
88\end{array}$ \\
\hline Balance & 12 & 7 & 1 & 2 \\
\hline \multicolumn{5}{|l|}{ dMet } \\
\hline Requirements ${ }^{4}$ & 62 & 66 & 62 & 63 \\
\hline Dietary supply & 73 & 75 & 67 & 66 \\
\hline Balance & 11 & 9 & 5 & 3 \\
\hline \multicolumn{5}{|l|}{ dLys } \\
\hline Requirements $^{4}$ & 186 & 197 & 185 & 184 \\
\hline Dietary supply & 208 & 219 & 187 & 190 \\
\hline Balance & 22 & 25 & 2 & 6 \\
\hline \multicolumn{5}{|l|}{ Supply of other AA, g/d } \\
\hline dArg & 140 & 147 & 122 & 122 \\
\hline dIle & 145 & 151 & 129 & 129 \\
\hline dLeu & 251 & 262 & 222 & 222 \\
\hline dPhe & 148 & 156 & 129 & 120 \\
\hline dThr & 140 & 145 & 127 & 131 \\
\hline dVal & 163 & 170 & 146 & 147 \\
\hline Total digestible EAA & 1,331 & 1,421 & 1,185 & 1,221 \\
\hline
\end{tabular}

${ }^{1}$ Values were estimated using NRC (2001) based on actual averaged DMI, milk yield and composition, and BW of cows during the experiment.

${ }^{2}$ MPA2.1 and MPA3.0 were formulated to supply adequate MP and 2.1 and $3.0 \%$ dHis of MP, respectively, according to NRC (2001). MPD2.1 and MPD3.0 were formulated to be around $80 \%$ deficient in MP and to supply dHis at 2.1 and $3.0 \%$ of MP, respectively.

${ }^{3}$ Intended dHis supply was calculated as \% of MP requirements based on treatment average of DMI and MY at the beginning of the experiment and were $2.1 \%$ and $3.0 \%$ for MPA2.1, MPD2.1 and MPA3.0, MPD3.0, respectively.

${ }^{4}$ Requirements of dMet and dLys were calculated as 2.2 and $6.6 \%$ of MP requirements, respectively (NRC 2001; Schwab et al., 2005).

\section{Dry Matter Intake; Milk Production and Composition}

The overall DMI was not affected by either MP or His level (Table 3 ), but there was dHis $\times$ wk interaction $(P=0.002)$; DMI being greater $(P=0.003)$ for dHis3.0 on experimental wk 7 (29.7 vs. $27.0 \mathrm{~kg} / \mathrm{d}$; SEM $=0.93$, but not different from dHis2.1 through the rest of the experiment (Figure 1). Milk yield was not affected by MP but tended to be greater $(P=0.10)$ for dHis3.0 compared with dHis2.1. There was a MP $\times$ His interaction $(P=0.001)$ for ECM yield; being increased
$(P=0.05)$ by greater dHis supply on the MPA diet (40.4 vs. $37.8 \mathrm{~kg} / \mathrm{d}$; $\mathrm{SEM}=0.92)$, whereas greater dHis supply on MPD diet tended to decrease $(P=0.08)$ ECM yield $(36.2$ vs. $38.5 \mathrm{~kg} / \mathrm{d} ; \mathrm{SEM}=0.90)$. Milk fat concentration was greater $(P=0.05)$ for cows fed MPA diets and there was a MP $\times$ His interaction $(P$ $=0.004)$ for milk fat yield; increasing dHis in the diet decreased $(P=0.004)$ milk fat yield on the MPD diets $(1.29$ vs. $1.49 \mathrm{~kg} / \mathrm{d} ; \mathrm{SEM}=0.05)$ but had no effect on the MPA diets (1.55 vs. $1.46 \mathrm{~kg} / \mathrm{d} ; \mathrm{SEM}=0.05)$. Milk true protein concentration and yield were similar across 
Table 3. Production data of mid-lactation dairy cows fed MP-adequate (MPA) or MP-deficient (MPD) diets with 2 levels of digestible (d)His

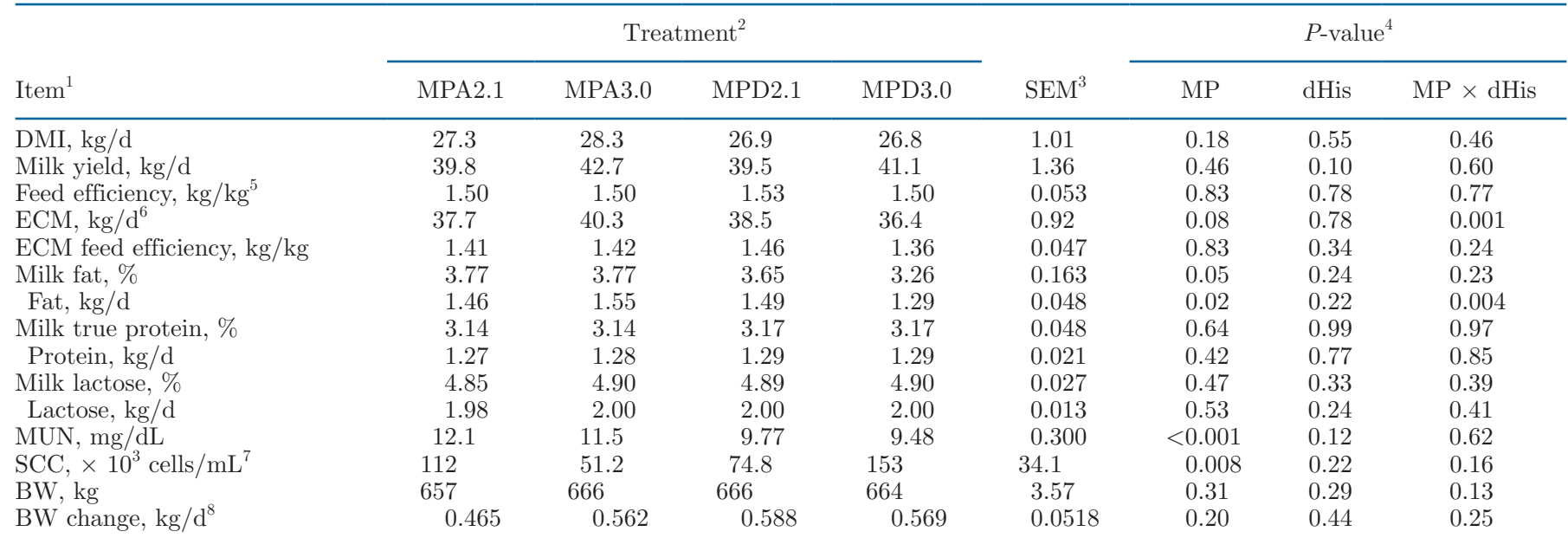

${ }^{1}$ DMI, MY, feed efficiency, and BW data were collected daily and averaged by experimental week; milk composition data are based on milk samples collected biweekly.

${ }^{2}$ MPA2.1 and MPA3.0 were formulated to supply adequate MP and 2.1 and 3.0\% dHis of MP, respectively, according to NRC (2001). MPD2.1 and MPD3.0 were formulated to be around $80 \%$ deficient in MP and to supply dHis at 2.1 and $3.0 \%$ of MP, respectively.

${ }^{3}$ Largest SEM published in table; $\mathrm{n}=470$ for DMI and MY, $\mathrm{n}=473$ for $\mathrm{BW}, \mathrm{n}=47$ for BW change, $\mathrm{n}=468$ for feed efficiency, $\mathrm{n}=236$ for milk composition variables ( $\mathrm{n}$ represents number of observations used in the statistical analysis). Data are presented as covariate-adjusted LSM.

${ }^{4}$ Main effect of MP $=$ MPA vs. MPD; main effect of dHis $=$ dHis at $3.0 \%$ of MP vs. dHis at $2.1 \%$ of MP; MP $\times$ dHis $=$ interaction between MP and dHis level. dHis $\times$ experimental week interactions: DMI, $P=0.002$; feed efficiency, $P=0.03 ;$ ECM feed efficiency, $P=0.02 ;$ MP $\times$ experimental week interaction: ECM feed efficiency, $P=0.03$.

${ }^{5}$ Milk yield $\div$ DMI

${ }^{6}$ Calculated according to Sjaunja et al. (1990).

${ }^{7}$ Statistical analysis was performed on $\log _{10}$-transformed data.

${ }^{8}$ Calculated as: (average BW on experimental wk 12 - average BW on covariate wk 2 ) $\div$ days on experiment.

treatments, whereas MUN concentration was greater $(P<0.001)$ for cows fed the MPA diets.

\section{Plasma and Muscle Amino Acid Concentrations}

Plasma concentration of Phe as well as the sum of EAA were lower $(P \leq 0.01)$ for cows fed MPD compared with MPA, and there was a MP $\times$ His interaction $(P \leq 0.03)$ for Ile, Leu, and Val (Table 4). Plasma concentration of His was not affected by MP level but was greater $(P<0.001)$ for cows fed dHis3.0 compared with dHis2.1, whereas Phe concentration tended to be greater $(P=0.07)$ for dHis2.1. Of the NEAA, plasma concentration of Glu and Tau were greater $(P \leq 0.02)$ and that of Gly $(P=0.05)$ was lower for cows fed MPD compared with MPA. Further, concentrations of Ala and the sum of NEAA tended to be greater $(P \leq$ $0.09)$ and that of Tyr tended to be lower $(P=0.08)$ for MPD compared with MPA. Glutamine concentration tended to be lower $(P=0.10)$, and there was a MP $\times$ His interaction $(P=0.04)$ for Tau concentration. Plasma concentration of carnosine, $1-\mathrm{MH}$ and $3-\mathrm{MH}$ were greater $(P \leq 0.03)$ for cows fed MPD compared with MPA. Further, there was a MP $\times$ experimental

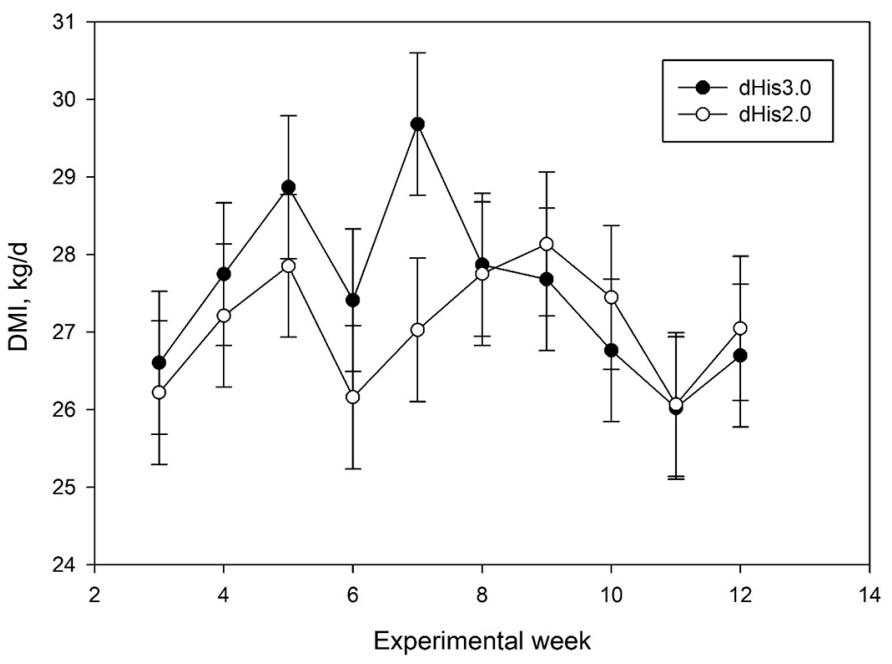

Figure 1. Effect of digestible His (dHis) on DMI of mid-lactation dairy cows over the course of the experiment. Treatments were dHis2.1 and dHis3.0, formulated according to NRC (2001), to supply dHis at $2.1 \%$ and $3.0 \%$ of MP, respectively. Data are covariate-adjusted LSM averaged over 2 levels of MP, and error bars represent SEM; $\mathrm{n}=470$. Effect of dHis level, $P=0.71$; effect of experimental week, $P<0.001$; $\mathrm{dHis} \times$ experimental week interaction, $P=0.006$. 
Table 4. Plasma AA and dipeptide concentrations $(\mu M)$ of mid-lactation dairy cows fed an MP-adequate (MPA) or MP-deficient (MPD) diet with 2 levels of digestible $(\mathrm{d}) \mathrm{His}$

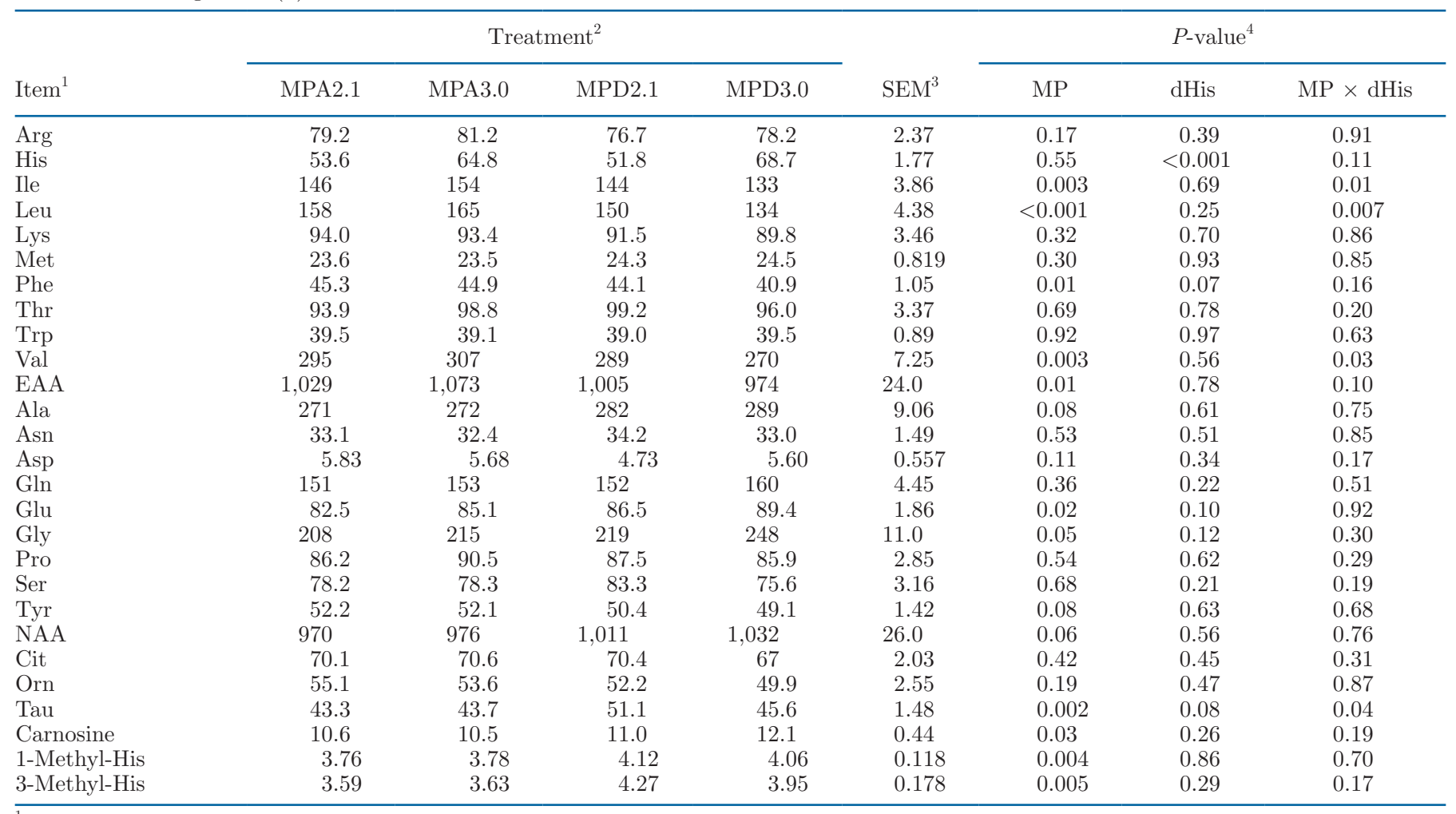

${ }^{1}$ Plasma samples were collected biweekly and composited as follows: 1 sample per cow for the covariate period, second sample per cow for wk 3 of the experimental period, a third sample for wk 4 , and a fourth composite sample per cow for wk $6,8,10$, and 12 .

${ }^{2}$ MPA2.1 and MPA3.0 were formulated to supply adequate MP and 2.1 and 3.0\% dHis of MP, respectively, according to NRC (2001). MPD2.1 and MPD3.0 were formulated to be around $80 \%$ deficient in MP and to supply dHis at 2.1 and $3.0 \%$ of MP, respectively.

${ }^{3}$ Largest SEM published in table; $\mathrm{n}=144$ ( $\mathrm{n}$ represents number of observations used in the statistical analysis). Data are presented as covariateadjusted LSM.

${ }^{4}$ Main effect of MP = MPA vs. MPD; main effect of dHis = dHis at 3.0\% of MP vs. dHis at $2.1 \%$ of MP; MP $\times$ dHis $=$ interaction between MP and dHis level. MP $\times$ experimental week interaction: 3 -Methyl-His, $P=0.005$.

week interaction $(P=0.005)$ for $3-\mathrm{MH}$ concentration; plasma concentration of $3-\mathrm{MH}$ was similar between MPD and MPA for wk 2 (3.42 vs. $3.29 \mu M$; SEM = 1.903), but greater $(P \leq 0.02)$ for MPD for wk $4(4.40$ vs. $3.60 \mu M)$ and the pooled plasma for wk 6 to $12(4.51$ vs. $3.94 \mu M$; Figure 2).

Muscle concentration of His tended to be greater $(P$ $=0.06)$ for MPD compared with MPA and was greater $(P<0.001)$ for dHis3.0 compared with dHis2.1 (Table 5; Figure 3). Concentrations of all other EAA were similar across treatments. Glycine and Ser concentrations were greater $(P \leq 0.003)$ for MPD compared with MPA, whereas Gly concentration was greater $(P$ $=0.03)$ and Ala, Asn and Asp concentrations tended to be greater $(P \leq 0.10)$ for dHis3.0 compared with dHis2.1. There was a MP $\times$ His interaction $(P \leq 0.02)$ for Ile, with concentration being greater $(P=0.04)$ for MPA3.0 compared with MPA2.1 but no difference between the 2 His levels for MPD. Concentrations of
$1-\mathrm{MH}$ and $\beta$-amino-isobutyric acid were greater $(P \leq$ $0.01)$, and $\gamma$-amino-butyric acid tended to be greater $(P$ $=0.10)$ for MPA compared with MPD. Concentration of $\beta$-alanine tended $(P=0.06)$ to be lower and hydroxylysine concentration greater for dHis 3.0 compared dHis2.1.

\section{Calculated His Pools}

Calculated His pools, apparent recovery of dHis in blood and milk pools as well as the apparent efficiency of His utilization are presented in Table 6. Apparent dHis recovery in milk was lower $(P=0.003)$ for MPA compared with MPD and dHis3.0 compared with dHis2.1 $(P<0.001)$. Similarly, apparent dHis recovery in blood pool and total His pool as well as Eff His $_{\text {were }}$ lower $(P<0.001)$ for MPA compared with MPD and dHis3.0 compared with dHis2.1, and there was a MP $\times$ His interaction $(P=0.04)$ for $\operatorname{Eff}_{\text {His }}$ (Figure 4$)$. 


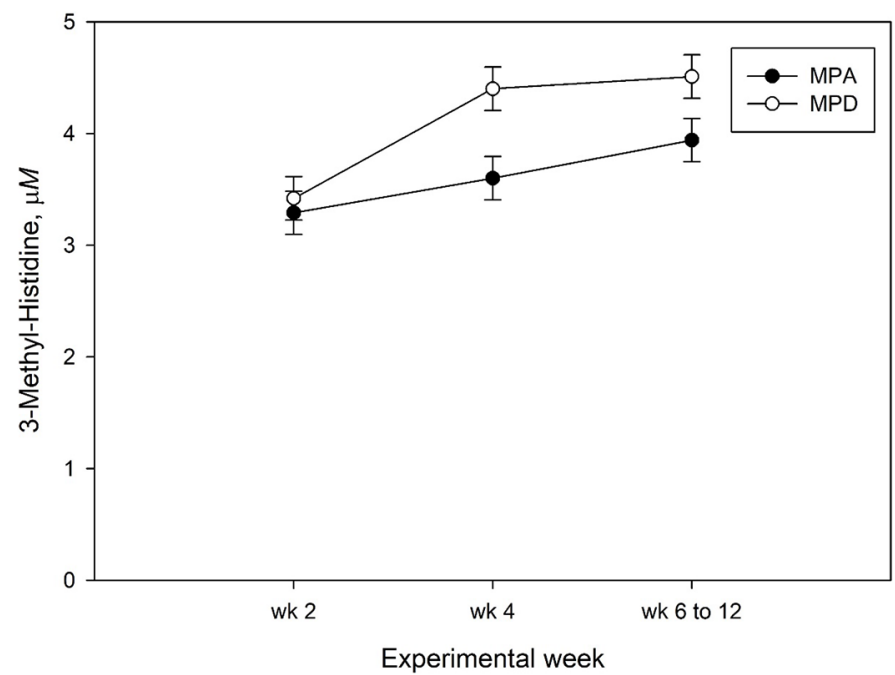

Figure 2. Effect of MP level on plasma 3-Methyl-His concentration $(\mu M)$ of mid-lactation dairy cows over the course of the experiment. $\mathrm{MPA}=$ diet formulated to supply adequate MP according to NRC (2001). MPD = diet formulated to be around $80 \%$ deficient in MP. Data are covariate-adjusted LSM, and error bars represent SEM; $\mathrm{n}=$ 144. Effect of MP level, $P=0.005$; effect of experimental week, $P<$ $0.001 ; \mathrm{MP} \times$ experimental week interaction, $P=0.005$.

\section{Enteric Gas Emissions}

Carbon dioxide and $\mathrm{CH}_{4}$ emissions were greater $(P$ $\leq 0.05$ ) for cows fed MPA compared with MPD diets (Table 7). Methane emission yield tended to be greater $(P=0.08)$ for MPA compared with MPD, and there was a MP $\times$ dHis interaction $(P=0.04)$ for ECM intensity so that MPA3.0 tended $(P=0.07)$ to have a lower $\mathrm{CH}_{4}$ emission intensity compared with MPA2.1, whereas emission intensity was similar for MPD2.1 and MPD3.0.

\section{Apparent Total-Tract Digestibility and Nitrogen Excretions}

Intake of nutrients, except for starch, were greater $(P$ $\leq 0.02$ ) during the fecal sampling period for cows fed MPA compared with those fed the MPD diet (Table 8). Apparent total-tract digestibility of all nutrients, except for starch, was greater $(P<0.001)$ for MPA compared with MPD. Level of dHis had no effect on intake or digestibility of dietary nutrients. There was a $\mathrm{MP} \times \mathrm{dHis}$ interaction $(P=0.007)$ for NDF digestibility; MPD3.0 had a greater $(P=0.003) \mathrm{NDF}$ digestibility compared with MPD2.1, but there was no difference between the 2 dHis levels for the MPA diet.

Nitrogen intake was greater $(P<0.001)$ for MPA compared with MPD but similar between the 2 His levels (Table 9$)$. Fecal $\mathrm{N}$ excretion was greater $(P=0.02)$ for cows fed MPA compared with MPD and tended to be greater $(P=0.09)$ for dHis3.0 versus dHis2.1. Total excreta $\mathrm{N}$ tended to be greater $(P=0.10)$ for cows fed MPA. Fecal $\mathrm{N}$ and milk $\mathrm{N}$ as $\%$ of $\mathrm{N}$ intake were lower $(P \leq 0.002)$ for MPA and fecal $\mathrm{N}$ was greater $(P=0.008)$ for dHis3.0, compared with dHis2.1. Total excreta $\mathrm{N}$ as $\%$ of $\mathrm{N}$ intake tended to be greater $(P=$ 0.06) for dHis3.0. Excretion of urinary PD were similar across treatments.

\section{DISCUSSION}

Target MP deficiency was formulated to be around $15 \%$ based on the production level and DMI at the end of the covariate period. However, the intended MP deficiency was not achieved due to decreased production level of the cows during the experiment (39.7 vs. $44.4 \mathrm{~kg} / \mathrm{d}$ ), and a greater-than-expected DMI (including GreenFeed bait feed). The decreased production level during the experiment may have masked the true MP deficiency of the cows. Estimated dHis supply was around $30 \mathrm{~g} / \mathrm{d}$ greater for dHis3.0 versus dHis2.1, whereas the MPD diets supplied around $10 \mathrm{~g} / \mathrm{d}$ less dHis compared with dHis supply from the corresponding MPA diets.

\section{Dry Matter Intake, Milk Production, and Composition}

The lack of effect of MP level on DMI is in agreement with Giallongo et al. (2015) and Lee et al. (2015) with cows fed corn silage-based diet supplying 95 and $90 \%$ of MP requirements and with $\mathrm{CP}$ content of 14.8 and $13.7 \%$ of DM, respectively. The MPD diet in the current experiment was very close to NRC (2001) recommendations, and therefore similar DMI between the 2 basal diets could be expected. Low-protein diets can reduce DMI, if dietary RDP supply is not sufficient to sustain ruminal microbes, and ruminal digestibility of nutrients is decreased (Giallongo et al., 2015). The RDP supply in the current experiment was not markedly below NRC (2001) recommendations due to urea supplementation of the MPD diets, and therefore the MPD diets did not compromise rumen function to the extent that would affect passage rate, and thereby DMI and supply of nutrients to the small intestine. Apparent total-tract digestibility of nutrients was decreased by MPD (see below), but not severely enough to compromise cow performance. Additionally, replacement of soybean meal with corn in the MPD diets, increased the amount of carbohydrates supplied to the rumen enhancing the uptake of fermentable energy, thus enhancing ruminal microbial growth (Russell et al., 1992). Similar DMI across treatments and thereby adequate supply of protein and energy from both MPD and MPA diets, resulted in a similar MY between the 2 MP levels. 
Cows on dHis3.0 treatment had a greater DMI during wk 7 of the experiment, but the overall DMI was not different between the 2 dHis levels. In 2 recent Latin square experiments from our research group, no effects of RPHis supplementation on DMI were reported with MPA (Räisänen et al., 2021a) or MPD (Räisänen et al., 2021b) basal diets. Similarly, no effects of His supplementation on DMI were reported in 2 Latin square experiments with corn silage-based diets, with one supplementing incremental levels of RPHis (Zang et al., 2019) and the other abomasally infusing incremental levels of His (Lapierre et al., 2021). However, a meta-analysis including 20 published experiments with His supplementation revealed that supplemental His increased DMI $(P=0.002)$ by $0.22 \mathrm{~kg} / \mathrm{d}$ (Räisänen and Hristov, 2021). Indeed, previous long-term continuous design experiments, reported a negative effect of His deficiency on DMI, which was alleviated by His supplementation with MPD (Lee et al., 2012a; Giallongo et al., 2015) and MPA (Giallongo et al., 2017) basal diets. It was hypothesized by Räisänen et al. (2021a) that a longer term (more than $4 \mathrm{wk}$ ) of His deficiency is needed for a DMI depression to occur. However, in the current experiment, DMI of cows receiving a diet

Table 5. Muscle AA and dipeptide concentrations $(\mu \mathrm{g} / \mathrm{g})$ of mid-lactation dairy cows fed an MP-adequate (MPA) or MP-deficient (MPD) diet with 2 levels of digestible (d)His

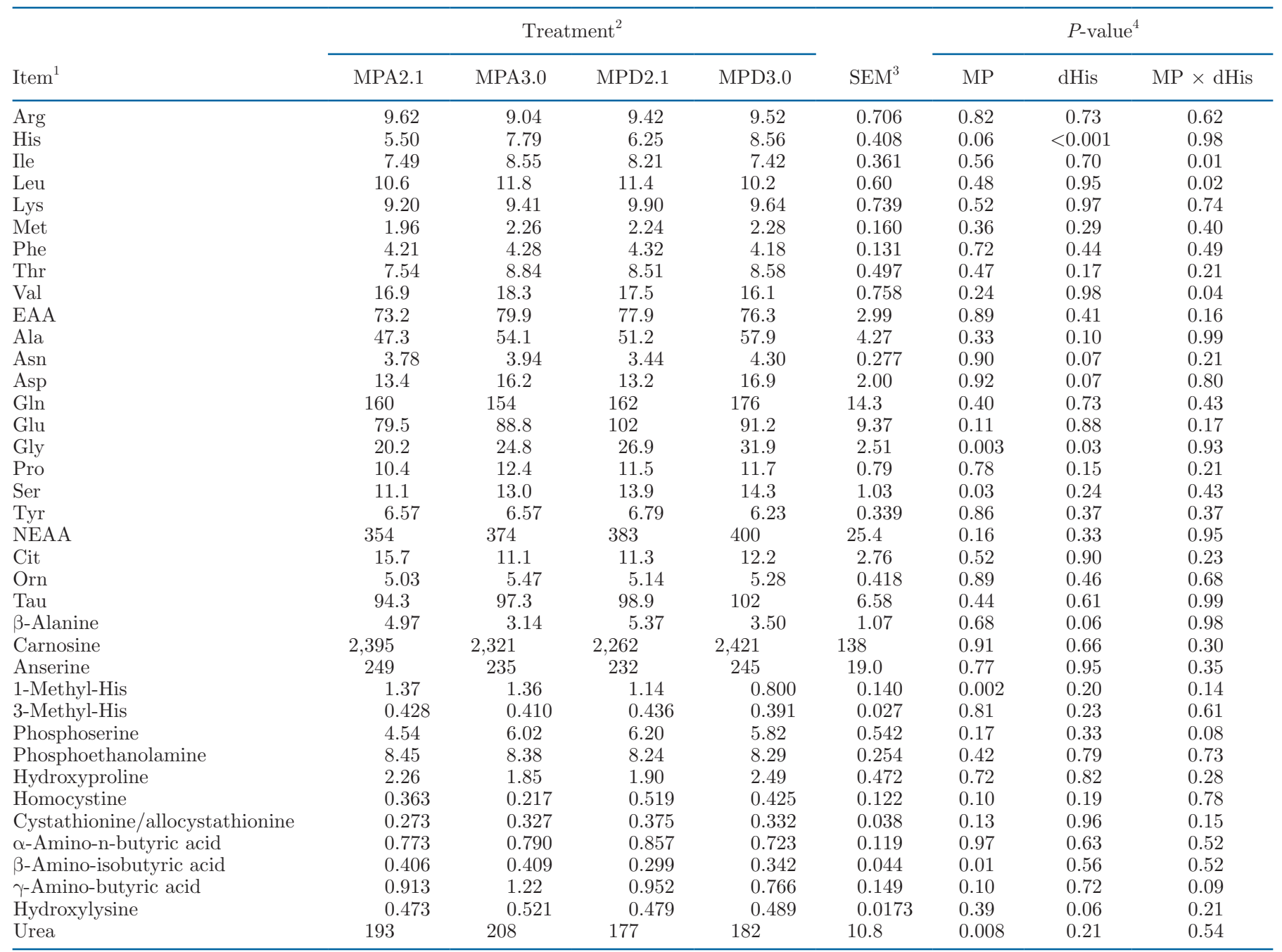

${ }^{1}$ Muscle samples were collected at the end of the covariate period and during wk 12 of the experimental period.

${ }^{2}$ MPA2.1 and MPA3.0 were formulated to supply adequate MP and 2.1 and 3.0\% dHis of MP, respectively, according to NRC (2001). MPD2.1 and MPD3.0 were formulated to be around $80 \%$ deficient in MP and to supply dHis at 2.1 and $3.0 \%$ of MP, respectively.

${ }^{3}$ Largest SEM published in table; $\mathrm{n}=47$ ( $\mathrm{n}$ represents number of observations used in the statistical analysis). Data are presented as covariateadjusted LSM.

${ }^{4}$ Main effect of MP $=$ MPA vs. MPD; main effect of dHis $=$ dHis at $3.0 \%$ of MP vs. dHis at $2.1 \%$ of MP; MP $\times$ dHis $=$ interaction between MP and dHis level. 


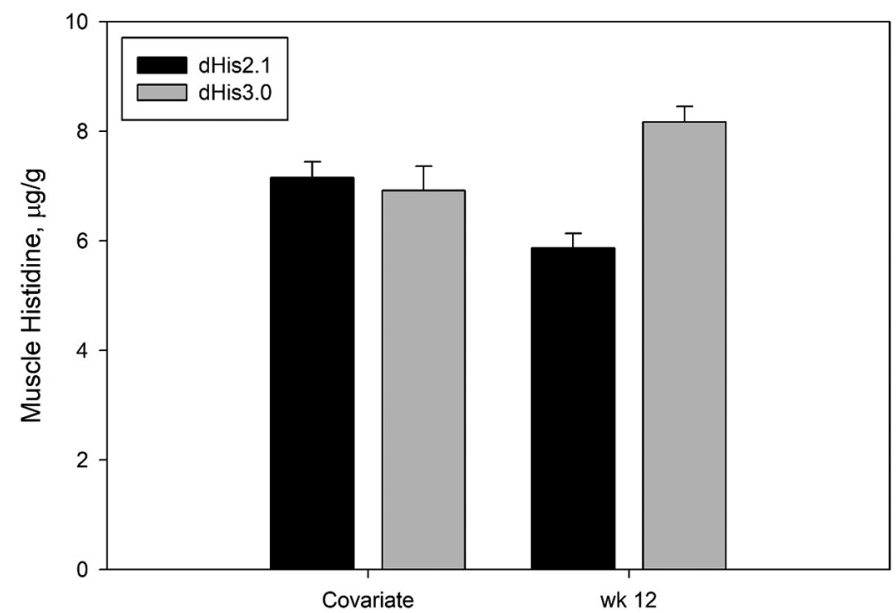

Figure 3. Effect of digestible (d)His on muscle His concentration $(\mu \mathrm{g} / \mathrm{g})$ of mid-lactation dairy cows. Treatments were dHis2.1 and dHis3.0, formulated according to NRC (2001), to supply dHis at 2.1 and $3.0 \%$ of MP, respectively. Data for wk 12 are covariate-adjusted LSM, and error bars represent SEM; $\mathrm{n}=47$. Effect of dHis level during wk $12, P<0.001$.

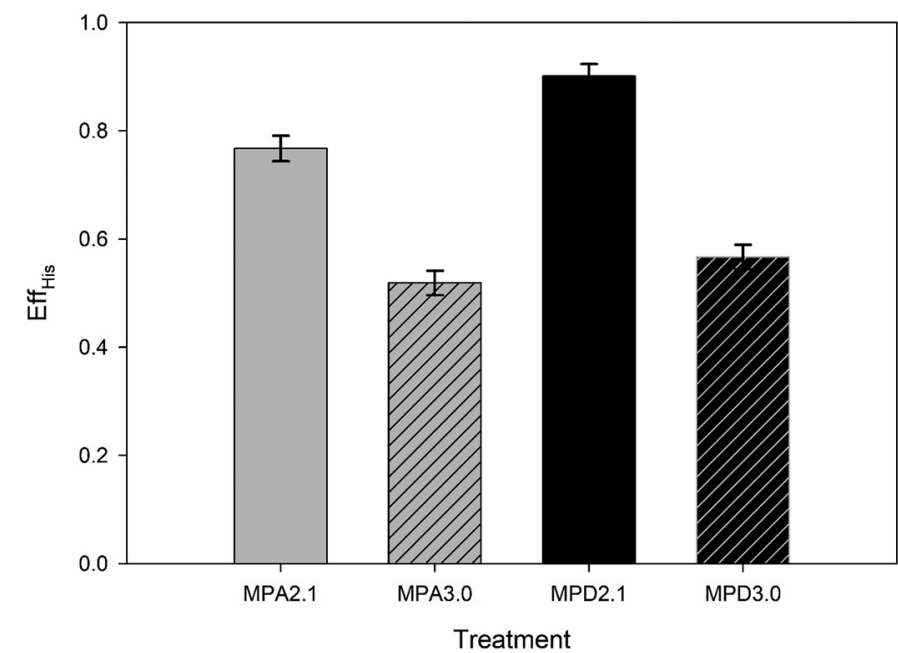

Figure 4. Apparent efficiency of His utilization (Eff $\mathrm{His}_{\mathrm{Hi}}$ ) of midlactation dairy cows fed MP-adequate (MPA) or MP-deficient (MPD) diets with 2 levels of digestible His (dHis), dHis2.1 and dHis3.0, respectively. MPA2.1 and MPA3.0 were formulated to supply adequate MP according to NRC (2001), and 2.1 and $3.0 \%$ dHis of MP, and MPD2.1 and MPD3.0 were formulated to be around $80 \%$ deficient in MP and to supply 2.1 and $3.0 \%$ of MP, respectively, according to NRC (2001). Data are LSM, and error bars represent SEM; $n=47$. Effect of dHis level, $P<0.001$; effect of MP level, $P<0.001 ; \mathrm{MP} \times \mathrm{dHis}$ interaction, $P=0.04$.

Table 6. Estimated digestible (d)His intake, body His pools, and apparent recovery of dHis in milk of mid-lactation dairy cows fed an MPadequate (MPA) or MP-deficient (MPD) diet with 2 levels of (d)His

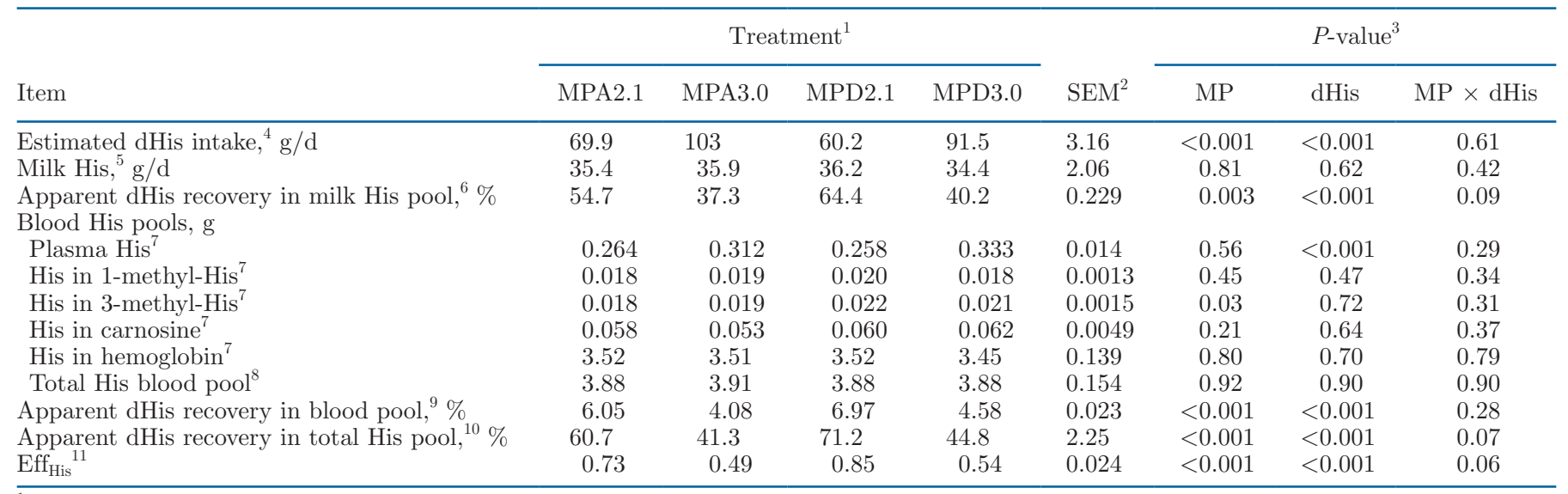

${ }^{1}$ MPA2.1 and MPA3.0 were formulated to supply adequate MP and 2.1 and 3.0\% dHis of MP, respectively, according to NRC (2001). MPD2.1 and MPD3.0 were formulated to be around $80 \%$ deficient in MP and to supply dHis at 2.1 and $3.0 \%$ of MP, respectively.

${ }^{2}$ Largest SEM published in table; $\mathrm{n}=47$ ( $\mathrm{n}$ represents number of observations used in the statistical analysis). Data are presented as LSM.

${ }^{3} \mathrm{MP}=\mathrm{MPA}$ vs. MPD; $\mathrm{dHis}=\mathrm{dHis}$ at $3.0 \%$ of MP vs. $\mathrm{dHis}$ at $2.1 \%$ of MP; MP $\times$ dHis = interaction between MP and $\mathrm{dHis}$ level.

${ }^{4}$ Estimated using NRC (2001) based on the individual cow DMI, MY, and milk composition during the experiment, and includes dHis from basal diet and rumen-protected His.

${ }^{5}$ Calculated as milk CP concertation $(\%) \times$ milk His concentration, $\%$ of milk $\mathrm{CP} \times \mathrm{MY}(\mathrm{kg} / \mathrm{d})$. Milk His concentration was assumed to be $2.7 \%$ of milk CP, based on data by Lee et al. (2015).

${ }^{6}$ Calculated as milk His $(\mathrm{g} / \mathrm{d}) \div$ dHis intake $(\mathrm{g} / \mathrm{d}) \times 100$.

${ }^{7}$ Calculated based on an assumed blood volume of $6.7 \%$ of BW and plasma volume of $68 \%$ of blood volume (Reynolds, 1953 ).

${ }^{8}$ Sum of plasma His (g) and His in 1-methyl-His, 3-methyl-His, carnosine, and blood hemoglobin.

${ }^{9}$ Calculated as total His in blood $(\mathrm{g}) \div$ dHis intake $(\mathrm{g} / \mathrm{d}) \times 100$.

${ }^{10}$ Calculated as [total His in blood $(\mathrm{g})+$ milk His $\left.(\mathrm{g} / \mathrm{d})\right] \div$ dHis intake $(\mathrm{g} / \mathrm{d}) \times 100$.

${ }^{11}$ Apparent efficiency of His utilization: calculated as sum of His in true exported proteins $(\mathrm{g}) \div[\mathrm{dHis}$ flow $(\mathrm{g} / \mathrm{d})-$ endogenous urinary His excretion $(\mathrm{g} / \mathrm{d})]$. For details see Material and Methods section. 
Table 7. Enteric gas emissions of mid-lactation dairy cows fed an MP-adequate (MPA) or MP-deficient (MPD) diet with 2 levels of digestible (d)His

\begin{tabular}{|c|c|c|c|c|c|c|c|c|}
\hline Item $^{1}$ & \multicolumn{4}{|c|}{ Treatment $^{2}$} & $\mathrm{SEM}^{3}$ & \multicolumn{3}{|c|}{$P$-value ${ }^{4}$} \\
\hline$\overline{\mathrm{CO}_{2}, \mathrm{~g} / \mathrm{d}}$ & 13,745 & 14,002 & 13,150 & 13,475 & 306 & 0.05 & 0.31 & 0.90 \\
\hline $\mathrm{H}_{2}, \mathrm{~g} / \mathrm{d}$ & 2.06 & 2.16 & 1.95 & 1.70 & 0.161 & 0.06 & 0.96 & 0.20 \\
\hline $\mathrm{CH}_{4}$ per DMI, $\mathrm{g} / \mathrm{kg}$ & 15.6 & 15.5 & 13.9 & 14.7 & 0.77 & 0.08 & 0.60 & 0.53 \\
\hline $\mathrm{CH}_{4}$ per milk yield, $\mathrm{g} / \mathrm{kg}$ & 10.6 & 9.46 & 9.32 & 9.23 & 0.48 & 0.12 & 0.19 & 0.26 \\
\hline
\end{tabular}

${ }^{1}$ Enteric gas emission data were collected daily and averaged biweekly over the experimental weeks.

${ }^{2}$ MPA2.1 and MPA3.0 were formulated to supply adequate MP and 2.1 and 3.0\% dHis of MP, respectively, according to NRC (2001). MPD2.1 and MPD3.0 were formulated to be around 80\% deficient in MP and to supply dHis at 2.1 and 3.0\% of MP, respectively.

${ }^{3}$ Largest SEM published in table; $\mathrm{n}=212$. Data are presented as covariate-adjusted LSM.

${ }^{4} \mathrm{MP}=\mathrm{MPA}$ vs. MPD; $\mathrm{dHis}=\mathrm{dHis}$ at $3.0 \%$ of $\mathrm{MP}$ vs. $\mathrm{dHis}$ at $2.1 \%$ of $\mathrm{MP} ; \mathrm{MP} \times \mathrm{dHis}=$ interaction between $\mathrm{MP}$ and $\mathrm{dHis}$ level; $\mathrm{H}_{2}, \mathrm{MP} \times$ week interaction $P=0.05$.

supplying 64 (MPA2.1) or $57 \mathrm{~g} / \mathrm{d}$ (MPD2.1) of dHis for 12 wk was not compromised regardless of MP level. This is in contrast to the previous findings by Lee et al. (2012a) and Giallongo et al. (2015, 2017), where supply of dHis from control diet was 44,59 , or $49 \mathrm{~g} / \mathrm{d}$, respectively. The greater-than-expected MP balance for the MPD diets in the current experiment may have masked the possible interaction of MP and His level in regard to DMI of the cows. Feed intake is regulated by a complex combination of hormones and signaling molecules linked to nutrient supply (Allen, 2014). Hence, it would require experiments specifically designed to study His effects on feed intake regulation in dairy cows to confirm the hypothesis of His acting directly or indirectly as a signaling molecule in feed intake, as discussed in Giallongo et al. (2015) and Räisänen et al. (2021a).

An additional $30 \mathrm{~g} / \mathrm{d}$ of dHis from RPHis compared with basal diet tended to increase MY by $2.2 \mathrm{~kg} / \mathrm{d}$, regardless of MP level, in the current experiment (Table 3). Overall, His supplementation has shown to increase MY in various dietary situations and sources of supplementation (an average increase of $0.36 \mathrm{~kg} / \mathrm{d}$, $P<0.001$, in the meta-analysis by Räisänen and Hristov, 2021). In a recent short-term crossover experiment from our laboratory, an increase up to $3.4 \mathrm{~kg} / \mathrm{d}$ between the lowest $(37 \mathrm{~g} / \mathrm{d}$ ) and greatest $(63 \mathrm{~g} / \mathrm{d})$ dHis supply were observed with an MPD basal diet supplying 85 to $90 \%$ of NRC (2001) MP requirements (Räisänen et al., 2021b). Another short-term crossover experiment

Table 8. Intakes and apparent total-tract digestibility of nutrients of mid-lactation dairy cows fed an MP-adequate (MPA) or MP-deficient (MPD) diet with 2 levels of digestible (d)His

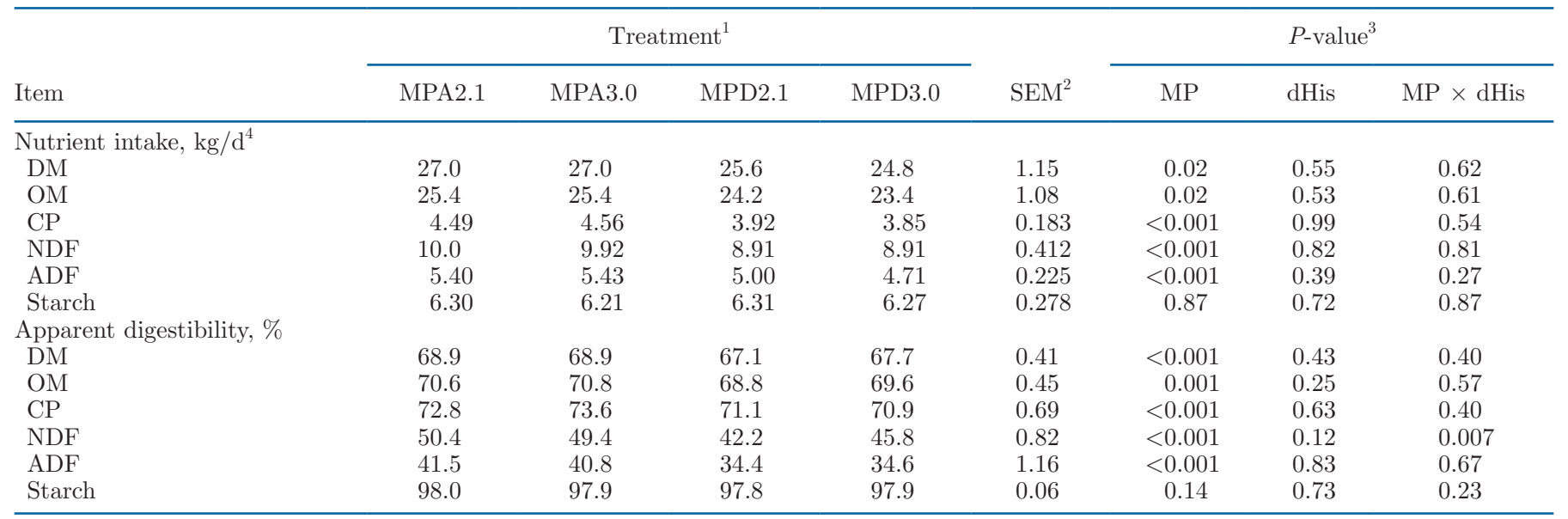

${ }^{1}$ MPA2.1 and MPA3.0 were formulated to supply adequate MP and 2.1 and 3.0\% dHis of MP, respectively, according to NRC (2001). MPD2.1 and MPD3.0 were formulated to be around $80 \%$ deficient in MP and to supply dHis at 2.1 and $3.0 \%$ of MP, respectively.

${ }^{2}$ Largest SEM published in table; $\mathrm{n}=47$. Data are presented as LSM.

${ }^{3} \mathrm{MP}=\mathrm{MPA}$ vs. MPD; $\mathrm{dHis}=\mathrm{dHis}$ at $3.0 \%$ of MP vs. dHis at $2.1 \%$ of MP; MP $\times$ dHis = interaction between MP and dHis level.

${ }^{4}$ Intake during the week of fecal collection, experimental wk 11. 
Table 9. Nitrogen utilization and urinary purine derivates excretion of mid-lactation dairy cows fed an MP-adequate (MPA) or MP-deficient (MPD) diet with 2 levels of digestible (d)His

\begin{tabular}{|c|c|c|c|c|c|c|c|c|}
\hline Item $^{1}$ & \multicolumn{4}{|c|}{ Treatment $^{2}$} & $\mathrm{SEM}^{3}$ & \multicolumn{3}{|c|}{$P$-value ${ }^{4}$} \\
\hline Urine N & 186 & 223 & 179 & 186 & 21.3 & 0.30 & 0.28 & 0.46 \\
\hline Urinary urea $\mathrm{N}$ & 175 & 181 & 164 & 171 & 17.7 & 0.50 & 0.68 & 0.98 \\
\hline Fecal N & 175 & 198 & 170 & 171 & 9.7 & 0.02 & 0.09 & 0.12 \\
\hline \multicolumn{9}{|l|}{ As $\%$ of $\mathrm{N}$ intake } \\
\hline Urine N & 25.6 & 31.5 & 29.2 & 31.5 & 3.58 & 0.53 & 0.17 & 0.55 \\
\hline Urinary urea N & 24.5 & 25.5 & 27.0 & 28.9 & 3.08 & 0.15 & 0.47 & 0.82 \\
\hline Fecal N & 24.3 & 27.0 & 27.0 & 27.7 & 0.68 & 0.004 & 0.006 & 0.08 \\
\hline Total excreta N & 49.9 & 58.4 & 56.3 & 59.2 & 3.44 & 0.24 & 0.06 & 0.35 \\
\hline Milk N & 27.7 & 27.2 & 31.4 & 31.4 & 1.36 & 0.002 & 0.81 & 0.82 \\
\hline \multicolumn{9}{|c|}{$\begin{array}{l}\text { Urinary purine derivate (PD) excretion, } \\
\mathrm{mmol} / \mathrm{d}\end{array}$} \\
\hline
\end{tabular}

${ }^{1}$ Urine samples were collected during experimental wk 11.

${ }^{2} \mathrm{MPD}=$ diets supplying MP at $97 \%$ of NRC (2001) recommendations; MPA = diets supplying MP at $110 \%$ of NRC (2001) recommendations.

${ }^{3}$ Largest SEM published in table; $\mathrm{n}=47$. Data are presented as LSM.

${ }^{4} \mathrm{MP}=\mathrm{MPA}$ vs. MPD; dHis $=\mathrm{dHis}$ at $3.0 \%$ of MP vs. dHis at $2.1 \%$ of MP; $\mathrm{MP} \times \mathrm{dHis}=$ interaction between MP and $\mathrm{dHis}$ level.

with incremental levels of abomasally infused His $(0$ to $30.4 \mathrm{~g} / \mathrm{d}$ ) reported a linear increase in MY up to $4 \mathrm{~kg} / \mathrm{d}$ compared with control (Lapierre et al., 2021). Similarly, long-term experiments with corn silage-based MPD (Lee et al., 2012a; Giallongo et al., 2015) and MPA (Giallongo et al., 2017) diets have reported 9, 4, and $8 \%$ increase in MY with RPHis supplementation (Lee et al., 2012a; Giallongo et al., 2015) or dHis supplied with the basal diet (49 vs. $68 \mathrm{~g} / \mathrm{d}$, Giallongo et al., 2017), respectively. The minimal MP deficiency for the MPD diets and similar DMI among treatments in the current experiment likely contributed to the lack of $\mathrm{MP} \times$ His interaction in terms of MY response. These findings further support the conclusions from Räisänen et al. $(2021 \mathrm{a}, \mathrm{b})$ that the extent and length of His deficiency, degree and type of His supplementation, type of basal diet and supply of MP and other AA from the basal diet will affect the magnitude of MY response to His supplementation.

The response in milk true protein concentration to different types of His supplementation has been inconsistent across experiments. In accordance with the current experiment, Lee et al. (2012a), Zang et al. (2019), and Räisänen et al. (2021a) reported no effect of RPHis supplementation on milk true protein concentration in cows fed corn silage-based diets. However, a linear trend for increased milk true protein concentration with increasing dHis dose from RPHis with an MPD basal diet was observed in Räisänen et al. (2021b), as well as with postruminal infusion of His with grass silage-based diet (Huhtanen et al., 2002) and RPHis supplementation of an MPD corn silage-based diet (Giallongo et al., 2015). Milk true protein yield, on the other hand, has shown a fairly consistent positive response to His supplementation, with an average increase of $0.31 \mathrm{~kg} / \mathrm{d}(P<0.001)$ reported across 20 experiments with supplemental RPHis or free His infused postruminally (Räisänen and Hristov, 2021). Indeed, several experiments with RPHis supplementation on MPD (Giallongo et al., 2015; Zang et al., 2019; Räisänen et al., 2021b) and MPA (Giallongo et al., 2017) corn silage-based diets reported increased milk protein yields. Infusion studies with corn silage-based (Lapierre et al., 2021) and grass silage-based diets (Korhonen et al., 2000; Huhtanen et al., 2002) have also reported a positive milk true protein yield response to postruminal infusion of His. However, incremental dHis levels supplemented in the form of RPHis on an MPA corn silage-based diet did not result in increased milk true protein yield (Räisänen et al., 2021a), in line with data from the current experiment. The milk true protein response to His supplementation, or lack thereof, can be affected by the type (RPHis vs. L-His) and site (TMR or abomasal infusion) of His supplementation, and more importantly, by dietary RUP supply (Lapierre et al., 2021). The cow becomes more reliant on microbial protein as a source of dEAA with low RUP diets (MPD or grass silage-based diets), and therefore less His is supplied to the small intestine 
because the concentration of His in microbial protein is low in relation to its concentration in milk protein (Kim et al., 1999; Räisänen et al., 2021b). As a result, low RUP diets may result in greater milk true protein response when dietary supply of His is increased compared with diets supplying adequate RUP. Räisänen et al. (2021a) indicated that additional supplemental His was directed elsewhere in the body than milk protein synthesis when MP was not deficient. This is supported by the data from the current experiment, as muscle His concentration was greater for dHis3.0 (see below).

Milk fat concentration was $8 \%$ lower for MPD compared with MPA diet. We hypothesize that this can be partly due to a greater NFC ( 45 vs. $43 \%$ of DM) and starch ( 25 vs. $23 \%$ of DM) amounts in MPD versus MPA diet, as readily fermentable carbohydrates from the diet can alter rumen biohydrogenation pathways and cause depression in milk fat synthesis (Bauman and Griinari, 2003). The observed MP $\times$ His interaction for milk fat yield might have been a combined effect of shift in ruminal biohydrogenation and a change in the balance of absorbed AA when a low-protein diet (MPD) was supplemented with RPHis. Greater circulating His concentration can lead to decreased mammary blood flow and thereby decreased availability of glucose, acetate and BHB at the mammary gland (Cant et al., 2003; Räisänen et al., 2021b).

As expected, MUN concentration was lower for MPD compared with MPA diet. When dietary protein concentration of dairy cow rations is decreased, a subsequent decrease in MUN concentration is commonly observed (Jonker et al., 1998; Lee et al., 2012a; Giallongo et al., 2015). This can be attributed to a more efficient use of $\mathrm{NH}_{3}$ in the rumen, as well as less urea being formed from excess $\mathrm{N}$ from $\mathrm{AA}$ not required by the animal and being eliminated as urea $\mathrm{N}$ in urine (Nousiainen et al., 2004).

\section{Plasma and Muscle Amino Acid Concentrations}

As expected, plasma concentration of EAA were lower for cows fed MPD compared with MPA diet. Lower dietary supply of protein will lead to less AA being absorbed at the small intestine and consequently lower plasma concentration of AA (Broderick et al., 1974). Further, the tissue uptake of available AA will increase and the efficiency of use of AA will increase to compensate for lower dietary supply of AA (Cant et al., 2018; Omphalius et al., 2019), which also partly contributes to lower plasma concentration of EAA when diets supplying less MP are being fed. Indeed, the estimated Ef$\mathrm{f}_{\text {His }}$ was greater for cows fed MPD compared with cows fed MPA (see below), indicating an increased efficiency of apparent His utilization for milk protein synthesis with the latter diets. Interestingly, muscle concentrations of EAA were not different between MPD and MPA diets, further suggesting that cows on MPD diet were receiving enough AA from the diet and microbial protein to support the same level of production as cows on MPA diet without needing to mobilize EAA (other than His) to support milk protein synthesis. However, plasma concentration of His containing molecules (1$\mathrm{MH}, 3-\mathrm{MH}$, and carnosine) were greater whereas the muscle concentration of $1-\mathrm{MH}$ was lower for cows on MPD diets, which does point to mobilization of these dipeptides and protein from the muscle tissue and may have partially masked the His deficiency and lead to lack of difference in milk protein yield between the 2 MP levels. This is also supported by the fact that the concentration of 3-MH was not different between the 2 MP levels at the beginning of the experiment (wk 2), but concentration of $3-\mathrm{MH}$ increased in cows fed the MPD diet over the course of the experiment, pointing to increased mobilization of muscle protein over time (Figure 2). Previous studies have shown mobilization of endogenous His to alleviate His shortages and partly mask the apparent dietary His deficiency (Lapierre et al., 2021). According to calculations by Giallongo et al. (2017), body reserves of His in form of muscle carnosine and hemoglobin could provide enough His for approximately $7 \mathrm{wk}$. In the current experiment, however, carnosine and hemoglobin were not affected despite the length of the experiment ( $12 \mathrm{wk}$ ), but other endogenous sources of His may have played a role, as discussed above. Lapierre et al. (2021) calculated that in their experiment labile pools of His may have contributed 1 to $2.3 \mathrm{~g} / \mathrm{d}$ of endogenous His. Albeit a relatively small amount, this additional His resulted in synthesis of an additional 33 and $77 \mathrm{~g} / \mathrm{d}$ milk true protein. The quantitative role of endogenous His pools as a source of His, and under what circumstances the different sources are mobilized, is not yet fully understood in the lactating dairy cow.

The lower muscle His concentration with dHis2.1 compared with dHis3.0, is in agreement with a previous continuous design experiment from our laboratory (Giallongo et al., 2017), as well as a Latin square experiment with incremental levels of RPHis by Zang et al. (2019). Giallongo et al. (2017) suggested that the decreased muscle concentration of His and an accompanying increase in $\beta$-alanine concentration points to a release of His from the muscle and a likely impaired synthesis of carnosine and anserine under His deficiency. This indicates, that despite the lack of milk true protein response to dHis3.0, dHis supply from dHis2.1 may have been insufficient in the current experiment, 
which is also suggested by $\mathrm{Eff}_{\text {His }}$ estimates (see following section). Mobilization of His from the muscle may have partly masked this deficiency and can explain the lack of milk true protein response to His supplementation. The lack of response in muscle carnosine and anserine concentrations to dHis level may have been due to the fact that these labile His pools can be released differently from individual muscles; when collecting biopsy samples from a single muscle, the mobilization of AA and peptides may not be reflective of whole-body mobilization of AA (Lapierre et al., 2021). It was suggested that pooled plasma samples may better represent the responses in whole-body tissue concentrations compared with concentrations measured in individual muscles (Lapierre et al., 2021). Indeed, the plasma dipeptide and methyl-His concentrations discussed above indicate a mobilization of labile His pools and muscle tissue in cows fed the MPD diet.

\section{Calculated His Pools}

As expected, apparent recovery of His in milk and Eff $_{\text {His }}$ decreased with increasing dHis supply. This is in line with data from our dose-response experiments (Räisänen et al., 2021a,b) as well as data by Lapierre et al. (2021). Further, MP level also affected the efficiency of His utilization, being greater with MPD compared with MPA diet. Even though the overall MP deficiency in the current experiment was marginal compared with the MP deficiency reported in Räisänen et al. (2021b), dHis supply was around $10 \mathrm{~g} / \mathrm{d}$ lower for MPD compared with MPA diet, and consequently, the efficiency of His utilization was lower at the greater MP level because milk true protein yields were similar across treatments. Lapierre et al. (2021) suggested the

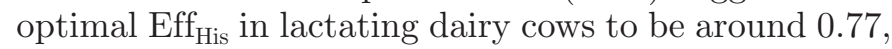
which was further confirmed in a short-term crossover experiment by Räisänen et al. (2021b). Based on this target efficiency, in the current experiment the dHis2.1 treatment was deficient in dHis for the MPD diet but at the target efficiency for the MPA diet, whereas dHis3.0 supplied dHis in excess regardless of MP level (Figure 4). Data from the current experiment further confirm the complexity of defining the optimal supply of His in lactating dairy cows, as also discussed in Lapierre et al. (2021). The complex and unclear role of labile His pools (muscle dipeptides and hemoglobin), and mobilization of His from muscle tissue, complicate the establishment of His deficiency and requirements in lactating dairy cows. Indeed, the mobilization of dipeptides and muscle His may have masked the His deficiency for dHis2.1 in the current experiment indicated by the Eff $_{\mathrm{His}}$ calculations.

\section{Enteric Gas Emissions}

The greater emissions on the MPA diet can be partly explained by the numerically greater DMI intake of these cows, as DMI is driving enteric $\mathrm{CH}_{4}$ emissions in ruminants (Hristov et al., 2013a). However, $\mathrm{CH}_{4}$ yield per kg DMI tended to be greater for MPA compared with MPD. This was most likely a result of a greater NFC and starch content of MPD diet. Highly fermentable carbohydrates cause a shift in the fermentation pathways in the rumen, shifting the VFA production more toward propionate, and away from acetate, that yields more $\mathrm{CH}_{4}$. Hence, less $\mathrm{CH}_{4}$ is formed when highly fermentable $\mathrm{CHO}$ are available in the rumen (Johnson and Johnson, 1995). The greater $\mathrm{CH}_{4}$ emission intensity was a result of a greater $\mathrm{CH}_{4}$ emission with MPA diet combined with similar MY between these diets (Hristov et al., 2013b).

\section{Apparent Total-Tract Digestibility and Nitrogen Excretions}

The greater intake of nutrients by cows fed MPA diet was a result of a greater DMI during the fecal sample collection event on wk 11 of the experiment. Starch content of the MPD diet was greater compared with MPA diet, and therefore no difference in starch intake was observed. Interestingly, digestibility of all nutrients except for starch was greater for MPA diet compared with MPD diet. Previous experiments from our laboratory with MPA and MPD diets, have reported decreased digestibility with MPD diets (Lee et al., 2012a,b; Giallongo et al., 2015). With low-protein diets the proportion of endogenous proteins increases and contributes to the decreased apparent digestibility of $\mathrm{CP}$ (Giallongo et al., 2015). Further, even though the MPD diet had similar RDP to the MPA diet, RDP supply from true protein may have been limiting digestibility in cows fed the former diet, as discussed in Giallongo et al. (2015). Indeed, previous research has shown that microbial growth and protein synthesis can be enhanced by supplying NAN and AA to the rumen (Argyle and Baldwin, 1989; Clark et al., 1992; Broderick and Reynal, 2009), and thus enhancing rumen fermentation. There was, indeed, a MP $\times$ His interaction; cows fed MPD3.0 had a greater NDF digestibility compared with MPD2.1, whereas cows fed the MPA diet had similar NDF digestibility regardless of His level. This may suggest a beneficial effect on ruminal fermentation of His released in the rumen from RPHis for the MPD diets. In the case of MPD3.0 an estimated $62 \mathrm{~g} / \mathrm{d}$ may have been released in the rumen from the RPHis product (assuming a $52 \%$ rumen escape of the experimental RPHis 
product used), which may have stimulated microbial fermentation, compared with MPD2.1 (no RPHis supplemented). Data on specific effects of His on microbial growth and fermentation in the rumen are lacking. An in vitro experiment by Kajikawa et al. (2002) identified 7 indispensable AA (Leu, Trp, Tyr, Glu, Met, Phe, and Val) as having stimulatory effect on ruminal bacterial growth. Adding His, Gly, and Cys resulted in some additional positive effects on microbial growth rates. It was suggested that considering the deficiency or excess of specific AA, rather than optimal combination, is a better way to stimulate microbial growth in the rumen (Kajikawa et al., 2002). In the current experiment, low true protein RDP supply (AA-N) with the MPD diet may have limited ruminal microbial growth efficiency and thereby rumen fermentation. The additional His available for the rumen microbes in the form of RPHis from the MPD3.0 diet may have partially alleviated this deficiency, as was indicated by the increased NDF digestibility for MPD3.0 vs. MPD2.1; this, however, was not supported by the urinary PD excretion data. Overall, the extent of RDP-deficiency, and subsequent negative effects on nutrient digestibility, was not severe enough to compromise the overall production of the cows on the MPD diets, as discussed above.

It is well established that diets with greater CP concentration will lead to greater urinary $\mathrm{N}$ excretion (Broderick, 2018) as was the case in the current experiment for MPA versus MPD. Excretion of both fecal N and total excreta $\mathrm{N}$ were greater for the MPA diets with CP concentration of 16.6 to $16.9 \%$ of DM compared with the MPD diets with CP of 15.3 to $15.5 \%$. Further, milk $\mathrm{N}$ as \% of $\mathrm{N}$ intake was greater for MPD diet, indicating that dietary $\mathrm{N}$ was more efficiently used of milk protein synthesis at lower dietary protein levels (Metcalf et al., 2008), which is supported by the lower MUN concentration and greater Eff ${ }_{\mathrm{His}}$ for MPD diet as discussed above. These data further emphasize that $\mathrm{CP}$ concentration of dairy diets can be reduced to around $15.5 \%$ of DM without detrimental effects on production resulting in increased milk $\mathrm{N}$ efficiency (Lee et al., 2015). This can be done as long as EAA and MP supply from the diet are sufficient, as was the case in the current experiment. The tendency for greater fecal $\mathrm{N}$ excretion for dHis3.0 indicated that part of the $\mathrm{N}$ from RPHis was not released at the small intestine but excreted in feces. Indeed, Räisänen et al. (2020) reported that around $24 \%$ of His from a fat-coated RPHis was recovered in feces.

\section{CONCLUSIONS}

In the conditions of the current long-term experiment, cows fed a corn silage-based diet supplying $110 \%$ of MP of NRC (2001) recommendations had similar milk and milk protein yield to cows fed a diet supplying MP at around $95 \%$ of requirements. Irrespectively of dietary MP, supplying dHis at 3.0 of MP (or 88-97 $\mathrm{g} /$ cow per day) increased MY and plasma and muscle concentrations of His, but had no or minor effects on milk composition and ECM yield in dairy cows. Calculated apparent efficiency of dHis utilization revealed that His may become deficient in diets supplying dHis at or below $57 \mathrm{~g} /$ cow per day.

\section{ACKNOWLEDGMENTS}

This work was supported by the USDA (Washington, DC) National Institute of Food and Agriculture Federal Appropriations under Project PEN 04539 and Accession Number 1000803. We want to thank Ajinomoto Co. Inc. (Tokoyo, Japan) for providing the experimental RPHis product and AjiPro-L, and for analyzing the plasma and muscle samples for AA. We also thank Sima Lionikaite and Melissa Welker (Animal Resource Program, The Pennsylvania State University) for their help with muscle biopsies, and Delaney Snyder (Department of Animal Science, The Pennsylvania State University) for her help with laboratory analysis. We also thank the management and staff of the Pennsylvania State University Dairy Research and Teaching Center for their help with the project and excellent care of the experimental cows. The authors have not stated any conflicts of interest.

\section{REFERENCES}

Allen, M. S. 2014. Drives and limits to feed intake in ruminants. Anim. Prod. Sci. 54:1513-1524. https://doi.org/10.1071/AN14478.

AOAC International. 2000. Official Methods of Analysis. 17th ed. AOAC International.

AOAC International. 2006. Official Methods of Analysis. 18th ed. AOAC International.

Argyle, J. L., and R. L. Baldwin. 1989. Effects of amino acids and peptides on rumen microbial growth yields. J. Dairy Sci. 72:20172027. https://doi.org/10.3168/jds.S0022-0302(89)79325-5.

Bauman, D. E., and J. M. Griinari. 2003. Nutritional regulation of milk fat synthesis. Annu. Rev. Nutr. 23:203-227. https://doi.org/ 10.1146/annurev.nutr.23.011702.073408.

Broderick, G. A. 2018. Review: Optimizing ruminant conversion of feed protein to human food protein. Animal 12:1722-1734. https:/ /doi.org/10.1017/S1751731117002592.

Broderick, G. A., and S. M. Reynal. 2009. Effect of source of rumendegraded protein on production and ruminal metabolism in lactating dairy cows. J. Dairy Sci. 92:2822-2834. https://doi.org/10 .3168/jds.2008-1865.

Broderick, G. A., L. D. Satter, and A. E. Harper. 1974. Use of plasma amino acid concentration to identify limiting amino acids for milk production. J. Dairy Sci. 57:1015-1023. https://doi.org/10.3168/ jds.S0022-0302(74)85002-2.

Cant, J. P., R. Berthiaume, H. Lapierre, P. H. Luimes, B. W. McBride, and D. Pacheco. 2003. Responses of the bovine mammary glands to absorptive supply of single amino acids. Can. J. Anim. Sci. 83:341-355. https://doi.org/10.4141/A02-077. 
Cant, J. P., J. J. M. Kim, S. R. L. Cieslar, and J. Doelman. 2018. Symposium review: Amino acid uptake by the mammary glands: Where does the control lie? J. Dairy Sci. 101:5655-5666. https:// doi.org/10.3168/jds.2017-13844.

Chen, X. B., Y. K. Chen, M. F. Franklin, E. R. Ørskov, and W. J. Shand. 1992. The effect of feed intake and body weight on purine derivative excretion and microbial protein supply in sheep. J. Anim. Sci. 70:1534-1542. https://doi.org/10.2527/1992.7051534x.

Clark, J. H., T. H. Klusmeyer, and M. R. Cameron. 1992. Microbial protein synthesis and flows of nitrogen fractions to the duodenum of dairy cows. J. Dairy Sci. 75:2304-2323. https://doi.org/10 .3168/jds.S0022-0302(92)77992-2.

Deyl, Z., J. Hyanek, and M. Horakova. 1986. Profiling of amino acids in body fluids and tissues by means of liquid chromatography. J. Chromatogr. 379:177-250. https://doi.org/10.1016/S0378 $-4347(00) 80685-4$.

Dijkstra, J., C. K. Reynolds, E. Kebreab, A. Bannink, J. L. Ellis, J. France, and A. M. Van Vuuren. 2013. Challenges in ruminant nutrition: Towards minimal nitrogen losses in cattle. Pages 47-58 in Energy and Protein Metabolism and Nutrition in Sustainable Animal Production, vol 134. J. W. Oltjen, E. Kebreab, H. Lapierre, ed. Wageningen Academic Publishers. https://doi.org/10.3920/ 978-90-8686-781-3_3

Fekkes, D. 1996. State-of-the-art of high-performance liquid chromatographic analysis of amino acids in physiological samples. J. Chromatogr. B Biomed. Appl. 682:3-22. https://doi.org/10.1016/0378 $-4347(96) 00057-6$

Giallongo, F., M. T. Harper, J. Oh, C. Parys, I. Shinzato, and A. N. Hristov. 2017. Histidine deficiency has a negative effect on lactational performance of dairy cows. J. Dairy Sci. 100:2784-2800. https://doi.org/10.3168/jds.2016-11992.

Giallongo, F., A. N. Hristov, J. Oh, T. Frederick, H. Weeks, J. Werner, H. Lapierre, R. A. Patton, A. Gehman, and C. Parys. 2015. Effects of slow-release urea and rumen-protected methionine and histidine on performance of dairy cows. J. Dairy Sci. 98:3292-3308. https:/ /doi.org/10.3168/jds.2014-8791.

Hall, M. B. 2009. Determination of starch, including maltooligosacchardies, in animal feeds: Comparison of methods and a recommended method for AOAC collaborative study. J. AOAC Int. 92:42-49. https://doi.org/10.1093/jaoac/92.1.42.

Hristov, A. N., M. Hanigan, A. Cole, R. Todd, T. A. McAllister, P. M. Ndegwa, and A. Rotz. 2011a. Review: Ammonia emissions from dairy farms and beef feedlots. Can. J. Anim. Sci. 91:1-35. https:/ /doi.org/10.4141/CJAS10034.

Hristov, A. N., C. Lee, T. W. Cassidy, M. Long, K. Heyler, B. Corl, and R. Forster. 2011b. Effects of lauric and myristic acids on ruminal fermentation, production, and milk fatty acid composition in lactating dairy cows. J. Dairy Sci. 94:382-395. https://doi.org/ 10.3168/jds.2010-3508.

Hristov, A. N., J. Oh, J. L. Firkins, J. Dijkstra, E. Kebreab, G. Waghorn, H. P. S. Makkar, A. T. Adesogan, W. Yang, C. Lee, P. J. Gerber, B. Henderson, and J. M. Tricarico. 2013b. Special topics - Mitigation of methane and nitrous oxide emissions from animal operations: I. A review of enteric methane mitigation options. J. Anim. Sci. 91:5045-5069. https://doi.org/10.2527/jas.2013-6583.

Hristov, A. N., J. Oh, C. Lee, R. Meinen, F. Montes, T. Ott, J. Firkins, A. Rotz, C. Dell, A. Adesogan, W. Z. Yang, J. Tricarico, E. Kebreab, G. Waghorn, J. Dijkstra, and S. Oosting. 2013a. Mitigation of greenhouse gas emissions in livestock production - A review of technical options for non- $\mathrm{CO}_{2}$ emissions. P. Gerber, B. Henderson, and H. Makkar, editors. FAO Animal Production and Health Paper No. 177. FAO.

Huhtanen, P., K. Kaustell, and S. Jaakkola. 1994. The use of internal markers to predict total digestibility and duodenal flow of nutrients in cattle given six different diets. Anim. Feed Sci. Technol. 48:211-227. https://doi.org/10.1016/0377-8401(94)90173-2.

Huhtanen, P., A. Vanhatalo, and T. Varvikko. 2002. Effects of abomasal infusions of histidine, glucose, and leucine on milk production and plasma metabolites of dairy cows fed grass silage diets. J. Dairy Sci. 85:204-216. https://doi.org/10.3168/jds.S0022 $-0302(02) 74069-1$.
Johnson, K. A., and D. E. Johnson. 1995. Methane emissions from cattle. J. Anim. Sci. 73:2483-2492. https://doi.org/10.2527/1995 $.7382483 x$.

Jonker, J. S., R. A. Kohn, and R. A. Erdman. 1998. Using milk urea nitrogen to predict nitrogen excretion and utilization efficiency in lactating dairy cows. J. Dairy Sci. 81:2681-2692. https://doi.org/ 10.3168/jds.S0022-0302(98)75825-4.

Kajikawa, H., M. Mitsumori, and S. Ohmomo. 2002. Stimulatory and inhibitory effects of protein amino acids on growth rate and efficiency of mixed ruminal bacteria. J. Dairy Sci. 85:2015-2022. https://doi.org/10.3168/jds.S0022-0302(02)74278-1.

Kim, C.-H., J.-J. Choung, and D. G. Chamberlain. 1999. Determination of the first-limiting amino acid for milk production in dairy cows consuming a diet of grass silage and a cereal-based supplement containing feather meal. J. Sci. Food Agric. 79:1703-1708. https: //doi.org/10.1002/(SICI)1097-0010(199909)79:12<1703::AIDJSFA424>3.0.CO;2-5.

Korhonen, M., A. Vanhatalo, T. Varvikko, and P. Huhtanen. 2000. Responses to graded postruminal doses of histidine in dairy cows fed grass silage diets. J. Dairy Sci. 83:2596-2608. https://doi.org/ 10.3168/jds.S0022-0302(00)75153-8.

Lang, C. H., R. A. Frost, N. Deshpande, V. Kumar, T. C. Vary, L. S. Jefferson, and S. R. Kimball. 2003. Alcohol impairs leucinemediated phosphorylation of 4E-BP1, S6K1, eIF4G, and mTOR in skeletal muscle. Am. J. Physiol. Endocrinol. Metab. 285:E1205E1215. https://doi.org/10.1152/ajpendo.00177.2003.

Lapierre, H., G. E. Lobley, and D. R. Ouellet. 2021. Histidine optimal supply in dairy cows through determination of a threshold efficiency. J. Dairy Sci. 104:1759-1776. https://doi.org/10.3168/jds 2020-19205.

Lee, C., F. Giallongo, A. N. Hristov, H. Lapierre, T. W. Cassidy, K. S. Heyler, G. A. Varga, and C. Parys. 2015. Effect of dietary protein level and rumen-protected amino acid supplementation on amino acid utilization for milk protein in lactating dairy cows. J. Dairy Sci. 98:1885-1902. https://doi.org/10.3168/jds.2014-8496.

Lee, C., A. N. Hristov, T. W. Cassidy, K. S. Heyler, H. Lapierre, G. A. Varga, M. J. de Veth, R. A. Patton, and C. Parys. 2012a. Rumenprotected lysine, methionine, and histidine increase milk protein yield in dairy cows fed a metabolizable protein-deficient diet. J. Dairy Sci. 95:6042-6056. https://doi.org/10.3168/jds.2012-5581.

Lee, C., A. N. Hristov, K. S. Heyler, T. W. Cassidy, H. Lapierre, G. A. Varga, and C. Parys. 2012b. Effects of metabolizable protein supply and amino acid supplementation on nitrogen utilization, milk production, and ammonia emissions from manure in dairy cows. J. Dairy Sci. 95:5253-5268. https://doi.org/10.3168/jds.2012-5366.

Metcalf, J., R. Mansbridge, J. Blake, J. Oldham, and J. Newbold. 2008. The efficiency of conversion of metabolisable protein into milk true protein over a range of metabolisable protein intakes. Animal 2:1193-1202. https://doi.org/10.1017/S1751731108002140.

Nousiainen, J., K. J. Shingfield, and P. Huhtanen. 2004. Evaluation of milk urea nitrogen as a diagnostic of protein feeding. J. Dairy Sci. 87:386-398. https://doi.org/10.3168/jds.S0022-0302(04)73178-1.

NRC (National Research Council). 2001. Nutrient Requirements of Dairy Cattle. 7th ed. National Academy Press.

Omphalius, C., H. Lapierre, J. Guinard-Flament, P. Lamberton, L. Bahloul, and S. Lemosquet. 2019. Amino acid efficiencies of utilization vary by different mechanisms in response to energy and protein supplies in dairy cows: Study at mammary-gland and whole-body levels. J. Dairy Sci. 102:9883-9901. https://doi.org/ 10.3168/jds.2019-16433.

Räisänen, S. E., and A. N. Hristov. 2021. Lactational performance of dairy cows receiving supplemental His: A meta-analysis. Abstract PSXIII-28 in 2021 ASAS-CSAS-SSASAS Annual Meeting.

Räisänen, S. E., C. F. A. Lage, M. E. Fetter, A. Melgar, A. M. Pelaez, H. A. Stefenoni, D. E. Wasson, S. F. Cueva, X. Zhu, M. Miura, and A. N. Hristov. 2021b. Histidine dose-response effects on lactational performance of lactating dairy cows: 2. Metabolizable protein-deficient diet. J. Dairy Sci. 104:9917-9930. https://doi.org/10 .3168/jds.2021-20189.

Räisänen, S. E., C. F. A. Lage, J. Oh, A. Melgar, K. Nedelkov, X. Chen, M. Miura, and A. N. Hristov. 2021a. Histidine dose-response 
effects on lactational performance of dairy cows: 1 . Metabolizable protein-adequate diet. J. Dairy Sci. 104:9902-9916. https://doi .org/10.3168/jds.2021-20188.

Räisänen, S. E., C. M. M. R. Martins, K. Nedelkov, J. Oh, M. T. Harper, A. Melgar, X. Chen, C. Parys, R. A. Patton, M. Miura, and A. N. Hristov. 2020. Bioavailability of rumen-protected methionine, lysine and histidine assessed by fecal amino acid excretion. Anim. Feed Sci. Technol. 268:114595. https://doi.org/10.1016/j .anifeedsci.2020.114595.

Reynolds, M. 1953. Measurement of bovine plasma and blood volume during pregnancy and lactation. Am. J. Physiol. 175:118-122. https://doi.org/10.1152/ajplegacy.1953.175.1.118.

Russell, J. B., J. D. O'Connor, D. G. Fox, P. J. Van Soest, and C. J. Sniffen. 1992. A net carbohydrate and protein system for evaluating cattle diets: I. Ruminal fermentation. J. Anim. Sci. 70:35513561. https://doi.org/10.2527/1992.70113551x.

Schneider, B. H., and W. P. Flatt. 1975. The Evaluation of Feeds through Digestibility Experiments. University of Georgia Press.

Schwab, C. G., P. Huhtanen, C. W. Hunt, and T. Hvelplund. 2005. Nitrogen requirements for cattle. Pages 13-70 in Nitrogen and Phosphorus Nutrition of Cattle and Environment. E. Pfeffer and A. N. Hristov, ed. CAB International.
Sjaunja, L. O., L. Baevre, L. Junkkarinen, J. Pedersen, and J. Setälä. 1990. A Nordic proposal for an energy corrected milk (ECM) formula. Pages 156-157 in 27th Session of the International Commission for Breeding and Productivity of Milk Animals, Paris, France. Wageningen Academic Publishers.

Van Soest, P. J., J. B. Robertson, and B. A. Lewis. 1991. Methods for dietary fiber, neutral detergent fiber, and nonstarch polysaccharides in relation to animal nutrition. J. Dairy Sci. 74:3583-3597. https://doi.org/10.3168/jds.S0022-0302(91)78551-2.

Vanhatalo, A., P. Huhtanen, V. Toivonen, and T. Varvikko. 1999. Response of dairy cows fed grass silage diets to abomasal infusions of histidine alone or in combinations with methionine and lysine. J. Dairy Sci. 82:2674-2685. https://doi.org/10.3168/jds.S0022 -0302(99)75524-4.

Zang, Y., L. H. P. Silva, M. Ghelichkhan, M. Miura, N. L. Whitehouse, M. L. Chizzotti, and A. F. Brito. 2019. Incremental amounts of rumen-protected histidine increase plasma and muscle histidine concentrations and milk protein yield in dairy cows fed a metabolizable protein-deficient diet. J. Dairy Sci. 102:4138-4154. https:// doi.org/10.3168/jds.2018-15780. 